\title{
The Effect of Economic Conditions on Accounting Conservatism under IFRS in Europe
}

\section{Antonio Cerqueira, ${ }^{1}$ Claudia Pereira ${ }^{2}$}

\begin{abstract}
We analyse in detail conservative accounting practices in seventeen European countries, taking into account institutional factors. In addition, we examine the impact of IFRS adoption and the influence of changes in economic conditions on conditional conservatism. Specifically, we study the level of accounting conservatism before and after IFRS adoption detailing for the pre and crisis period and post-crisis period surrounding the 2007/2008 financial crisis. Our findings are consistent with a conservative accounting practice in Europe as a whole and in each country individually. Besides, opposite to that expected, the results provide evidence of more conservative accounting practice in Anglo-Saxon countries, but we find no significant differences in conservatism in Nordic countries. Another finding is a significant decrease in the level of conservatism after IFRS adoption. Regarding the joint impact of IFRS adoption and economic conditions, we find a decrease in conservatism in the pre and crisis period, followed by a substantial increase in the post-crisis period. Our results seem to be in line with the positive accounting theory when suggesting that conservatism plays a fundamental role as corporate governance and efficient contracting mechanism between managers and other stakeholders of the firm. Furthermore, the results suggest that the flexibility provided by IFRS allows adjusting the level of conservatism when economic conditions change.
\end{abstract}

Keywords: Conditional Conservatism, Economic Conditions, IFRS, Institutional Factors

JEL classification: M41, G01, G32

\section{Introduction}

We study if the flexibility provided by IFRS allows managers to adjust accounting conservative practice under different economic conditions, in particular relating to the $2007 / 2008$ financial crisis. Given our concern with the effect of news events, we analyse conditional accounting conservatism that is usually defined as the tendency to require a higher degree of verification for the recognition of good news than for the recognition of bad news (Basu, 1997).

\footnotetext{
${ }^{1}$ University of Porto, School of Economics and Management, Porto, Portugal, acerqueira.pt@gmail.com

${ }^{2}$ Polytechnic of Porto, CEOS.PP - Center for Organisational and Social Studies of P. Porto, S. Mamede de Infesta, Portugal, claudial@iscap.ipp.pt
}

C 2020 by the authors; licensee Review of Economic Perspectives / Národohospodářský obzor, Masaryk University, Faculty of Economics and Administration, Brno, Czech Republic. This article is an open access article distributed under the terms and conditions of the Creative Commons Attribution 3.0 license, Attribution - Non Commercial - No Derivatives. 
The main motivation in this study is to analyse the effect of changes in economic conditions on financial reporting practices, specifically on conditional conservatism. The study of the impact of economic conditions on accounting and reporting practices matters because adverse conditions may lead to less informative financial statements, which in turn may induce market volatility and instability. Therefore, given the documented pervasiveness of conservative accounting over time and across countries, all the stakeholders should be aware that, for example in periods of economic downturn, managers may have incentives to alter accounting choices. For example, managers of firms facing economic difficulties may have incentives to delay the recognition of bad news, thus reducing the level of accounting conservatism (Gunn, Khurana and Stein, 2018; Vichitsarawong, Eng, and Meek, 2010). However, managers may also be aware that accounting conservatism plays an important role as an efficient contracting and governance mechanism that reduces information asymmetries and agency costs (Francis, Hasan, and Wu, 2013; Jenkins, Kane and Velury, 2009; LaFond and Watts, 2008; Ball and Shivakumar, 2005 and Basu, 1997). Therefore, conservatism is likely to help firms to recover in periods of economic downturn. Overall, we aim at providing a theoretical framework and empirical evidence that could help investors, creditors, policy-makers, accounting standard setters, and academics to understand accounting conservatism in different economic contexts.

To deepen the analysis, we provide some details about the costs and benefits of accounting conservatism. For that purpose, we need to consider the views of positive accounting theory and normative accounting regarding conservatism. Under positive accounting, conservatism is beneficial because it reduces managerial opportunism to alter accounting numbers to avoid violation of debt covenants and minimizes the risk of opportunistic payments in the form of compensation and dividends (LaFond and Roychowdhury, 2008). Even for equity markets, with asymmetric information between firm insiders and outside investors, conservative accounting may be seen as a governance mechanism that reduces managers' incentives to manipulate accounting numbers (Lafond and Watts, 2008) and reduces information asymmetries in equity market (Balakrishnan, Watts and Zuo, 2016 and Lara, Osma and Penalva, 2014). However, international accounting standard setters, namely the IASB, believe that conservatism biases accounting information and compromises neutrality (Barker and McGeachin, 2015 and Ruch and Taylor, 2015). However, despite the above reported criticism of regulators and standard setters who argue that conservatism may introduce a bias into accounting numbers, accounting standards are conceptually conditional conservative (Andre, Filip and Paugam, 2015) or exhibit some features in measurement requirements that lead to conditional conservatism (Barker and McGeachin, 2015).

When studying the association between economic conditions and conservatism, we must consider the characteristics of accounting standards underlying the preparation of financial statements. While IFRS relies on fair value accounting, which tends to overstate the accounting value of assets (Whalen, 2008), the flexibility underlying those standards may allow to adjust the level of conservatism to the economic environment. For example, in general terms the initial measurement is the historical cost, and in the subsequent measure, the fair value is optional (Barker and McGeachin, 2015). Furthermore, the effects of IFRS adoption on conditional conservatism are likely to vary across countries, depending on institutional factors. For example, in the case of European countries, existing research analyses the quality of auditing and the strength 
of accounting enforcement (Andre et al., 2015), cultural dimensions (Zeghal and Lahmar, 2018) and culture, legal system and equity market development (Fearnley and Gray, 2015).

Therefore, in this study we analyse multiple links between economic conditions, accounting standards, and conservatism. Firstly, accounting standards may have an impact on the quality of reported information and affect financial markets, for example, Trombetta and Imperatore (2014), Kothary and Lester (2012) argue that the use or misapplication of fair value accounting contributed to the expansion and globalization of the 2007/08 financial crisis. Secondly, economic conditions affect the characteristics of accounting information, for example, Trombetta and Imperatore (2014) report evidence that the impact of business cycles on earnings management depends on the intensity of the financial crisis. Thirdly, conservatism may play a role as an efficient contracting and governance mechanism (Watts, 2003). According to the Pecking Order Theory of capital structure (Myers and Majluf, 1984), firms prefer financing by internal funds rather than external funding. In periods of economic downturn, internal funding in some firms becomes scarce, and firms need external funding. Following the preference in the pecking order, firms prefer debt financing to equity financing, and conservative accounting plays an important role in obtaining debt in better terms. Taking into account these arguments, conservatism is expected to increase in periods of economic downturn.

Our sample consists of European listed companies from seventeen countries over the period from 1998 and 2018. Given that our sample includes diverse countries, we need to control for heterogeneity throughout our sample. Part of that heterogeneity is potentially driven by institutional factors, so a likely way to account for heterogeneity is to compare conditional conservatism between groups of countries formed on the basis of institutional factors, which are the legal system, the main source of financing and culture. Specifically, we organise the sample into Anglo-Saxon countries, Continental Europe countries, and Nordic countries.

Using the measures of conservatism proposed by Basu (1997) and Ball and Shivakumar (2005) we compare the levels of conservatism between different time periods, including periods before and after IFRS adoption in 2005 and sub-periods before and after the 2007/2008 financial crisis. In addition, we examine whether the level of conservatisms varies across countries with the intensity of the financial crisis and across groups of countries arranged on the basis of institutional factors and the sensitivity to the financial crisis.

We must emphasise that the main objective of this study is to investigate the effect of economic conditions on conditional conservatism, taking into account the characteristics of the accounting standards followed. For that purpose, we use two sub-periods, the subperiod from 2005 to 2008 and that from 2009 to 2012. Our main concern is to guarantee that financial statements in both sub-periods are prepared under the same accounting standards. Therefore, to ensure that all firms are reporting under the same standards, we collect a variable in Datastream known as "Accounting Standards Followed" and we only consider firm-year observations that follow IFRS. To account for the adoption of IFRS, we use the common approach based on a proxy that identifies firms that follow IFRS. 
This study contributes to the research in international accounting by providing evidence on conditional conservatism for a sample of seventeen European countries and the association between accounting conservatism, as an attribute of reported earnings, and real economic activity.

Such a relationship between accounting conservatism, accounting standards, and economic conditions, which is evidenced in our results, may potentially be useful for policy-makers, accounting standard setters, and academics. As stated by Watts (2003), the elimination of accounting conservatism would change managers' choices and impose significant costs on investors and on the economy. This is particularly evident given the concerns related to the widespread impact of the recent financial crisis (Mora and Walker, 2015). With respect to accounting setters, our results may assist by providing empirical evidence on the costs and benefits of conservatism. This could be particularly important given the accounting setter's arguments that conservatism compromises neutrality, and contributes to inefficient decision-making (Barker and McGeachin, 2015 and Ruch and Taylor, 2015). In addition, we contribute to the ongoing debate among academics regarding the balance between the stewardship role and the information role played by conservative accounting (Mora and Walker, 2015 and Sodan, Barac, and Vuko, 2013).

We develop our hypothesis based on a detailed theoretical and empirical literature review, and we provide evidence that can be considered as contributions of this study to prior literature. Firstly, conservative accounting practice is pervasive across the seventeen European countries of our sample and over the twenty-one years of the sample period. This finding may fuel the debate among accounting setters and academics on the extent to which certain attributes of financial reporting, such as conservatism, should be included as part of an accounting standard setting.

Secondly, in spite of being pervasive across countries, the results show that the level of accounting conservatism is higher in Anglo-Saxon countries relative to Continental Europe countries. Therefore, an accounting setting must provide some degree of flexibility to accommodate a demand for conservatism that could vary across countries.

Thirdly, using data at the country level, we provide evidence of a decline in conservatism after the mandatory adoption of IFRS. Such finding is consistent with Andre et al. (2015) that also report a decline in conservatism whilst using data at the firm level. This finding may reflect the IASB preference for neutrality rather than prudence.

Fourthly, conservatism decreases in the four-year window from 2005 to 2008 (pre and crisis period) and increases in the four-year post-crisis period, so to analyse the impact after the IFRS adoption in 2005 requires to account for the changes in economic conditions. We argue that such findings may reflect a certain degree of flexibility provided by accounting standards that allow managers to adjust their accounting choices according to their beliefs regarding the intensity and duration of the crisis. The interpretation of our results may be a key point for policy-makers and investors because they are consistent with managers becoming committed with a more conservative reporting corresponding to the demand from stakeholders. In fact, conservatism is likely to allow firms to obtain funding in better terms and helps them to recover from economic declines. 
Fifthly, the increase in conservatism in the post-crisis period depends on the intensity of the crisis as we find a stronger change for the countries more affected by the 2007/08 financial crisis. This result may provide an explanation for conflicting findings in prior studies regarding the impact of cycles of economic expansion and economic decline on conservatism and corroborates the finding of Trombetta and Imperatore (2014) about the non-monotonic effects of the crisis on earnings quality.

The remainder of this article is organized as follows. Section 2 displays the literature review and develops the hypotheses tested in the empirical study. Section 3 describes the empirical research design. Section 4 documents some descriptive statistics and reports the results of the empirical tests, and Section 5 presents some concluding remarks.

\section{Literature review and hypotheses development}

Accounting conservatism has been significantly present in accounting practice for a long time (Basu, 1997 and Watts, 2003). Previous studies identify two forms of accounting conservatism denoted by conditional conservatism and unconditional conservatism. These two forms differ because conditional conservatism depends on a news event, while unconditional conservatism does not (Ruch and Taylor, 2015). In this study, we analyse conditional accounting conservatism, which may be defined as the tendency to require a higher degree of verification for the recognition of profits than for the recognition of losses (Basu, 1997). Unconditional conservatism is defined as systematically reporting the lowest value among alternative values for assets and the highest alternative value for liabilities, independent from any news event (Ball and Shivakumar, 2005).

Extant literature reflects the ongoing debate among accounting setters and researchers about the costs and benefits of conservatism to accounting information users. On the one hand, the IASB and some researchers develop arguments that conservatism biases accounting information, compromises neutrality, thus contributing to inefficient decision-making (Barker and McGeachin, 2015 and Ruch and Taylor, 2015). Consistent with those arguments, conservatism is not included as a qualitative characteristic of financial reporting in the 2010 Conceptual Framework developed by IASB jointly with FASB. On the other hand, some researchers argue that conservatism arises because it is a mechanism that allows to design efficient contracts between stakeholders, for example, in debt and executive compensation contracts.

To deepen our understanding of conservatism from the perspective of financial statements users, we must take into account the informational role of financial reporting (Augusta, 2018 and Ruch, and Taylor, 2015). For equity market users, accounting information allows to assess the intrinsic value of equity, and it supports investment decisions. This requires on the part of investors and analysts to anticipate future cash flows and risk. Conservatism affects the expectations of future earnings, whilst it does not affect expected future cash-flows (Ruch and Taylor, 2015). However, conservatism reduces risk assessment, meaning a decrease in discount rates (Lara et al., 2014 and Francis et al., 2013). With lower discount rates, the present value of future cash-flows increases. 
For debt markets, accounting information allows contracting parties to evaluate if obligations in debt covenants were fulfilled or not. Covenants are expected to constrain managerial opportunism; however, only if the accounting system recognizes economic losses in earnings in a timely fashion (Nikolaev, 2010). In fact, conservative accounting anticipates potential decreases in income or assets but postpone the recognition of the increases, then such timely loss recognition allows creditors to detect the violation of debt covenants earlier and take protective actions (Balakrishnan et al., 2016; Nikolaev, 2010 and Zhang, 2008). In addition, lenders are expected to provide finance in better terms when borrowers report negative information in a timelier fashion relative to positive information (Balakrishnan et al., 2016 and Zhang, 2008).

Overall, conservatism reduces the opportunities for managers to alter accounting numbers to avoid violation of debt covenants and minimizes the risk of opportunistic payments in the form of compensation and dividends. Ball and Shivakumar (2005) state that timely loss recognition increases financial statement usefulness in general and, in particular, for corporate governance and debt agreements.

However, prior literature provides conflicting findings regarding the demand for conservatism between debt markets and equity markets. For example, LaFond and Roychowdhury (2008) find evidence suggesting demand for conservative reporting on the part of shareholders, while Ball, Robin, and Sadka (2008) find that debt markets, not equity markets, are primarily responsible for conservative accounting. Taking the above arguments, we posit our first hypothesis:

H1: European listed firms exhibit a conservative accounting practice.

To analyse in more detail conservatism in European countries, we need to take into account differences reported in prior literature regarding the impact of national institutional factors on accounting practice, for example, legal system, main source of financing and culture (Zeghal and Lahmar, 2018; Fearnley and Gray, 2015; Nobes, 1998 and Gray, 1988).

Regarding legal origin, in common-law countries, information asymmetries between managers and diverse groups of external shareholders are resolved by accounting information; thus timeliness is a fundamental attribute of earnings (Guenther and Young, 2000, and Ball, Kothari and Robin, 2000). In particular, Ball et al. (2000) find that accounting income is timelier in common-law countries relative to code-law countries, mainly due to the incorporation of economic losses, consistent with accounting conservatism. Such demand for conservative accounting may be explained by the asymmetric loss function of bondholders that benefit from earlier detection of violation of debt covenants in the case of timely loss recognition (Ball, Robin, and $\mathrm{Wu}$, 2003). Conversely, code-law countries tend to be more stakeholder-oriented; thus the measures of earnings must take into account the preferences of governments, creditors, employees, managers, and shareholders. For example, the government, employees, and banks prefer to have a stable income, resulting in allowing managers to exercise a certain degree of discretion when preparing financial statements. In this scenario, the major feature of financial reporting is not to mitigate problems of information asymmetry because they can be solved through insider communication. In code-law countries, information asymmetries among managers and stakeholders tend to be resolved by closer relations with major stakeholders, namely by providing private rather 
than public information (Guenther and Young, 2000 and Ali and Hwang, 2000). Consequently, the demand for timely public information in code-law countries is not as great as in common-law countries, and this reduces the demand for conservatism in code-law countries relative to common-law countries.

Concerning the main financing system, Nobes (2008) and Nobes (1998) develops a dichotomous classification of countries by the dominant accounting system based on the financing system and development of the equity market. In the case of developed countries (culturally self-sufficient) Class A countries are those with a strong equitybased financing system with shares extensively owned by outsiders. The remaining developed countries are arranged into Class B, which includes countries with strong credit financing or strong equity financing with shares owned mainly by insiders, for example, banks and other companies. Class A corresponds to Anglo-Saxon countries and Class B to continental European countries. In Class A systems, outsiders require more public disclosure of timely information. In Class B systems with a strong credit financing system, the protection of creditors is likely to lead to more conservative measures of profits and assets (Fearnley and Gray, 2015). Therefore, regarding financing systems, class $\mathrm{B}$ countries are expected to exhibit more conservative accounting practices.

A third external environment fundamental to understand accounting choices in European countries relies on accounting values. The Gray (1988) seminal paper builds on the influence of different social systems on the accounting values underlying accounting practice across countries. In the context of our study, we focus on the accounting value of conservatism versus optimism, where conservatism reflects a preference for a cautious approach in the exercise of judgements needed in making estimates under conditions of uncertainty. Based on Gray (1988), countries range from a conservative approach in Germanic and developed Latin countries, to an optimistic one in Anglo-Saxon and Nordic countries.

To build our second hypothesis about differences in conditional conservatism across European countries, we take into account the expected impact of the different theories regarding institutional factors. However, our approach relies on the analysis by groups of countries with similar characteristics, and we do not analyse the differences at the individual country level. Therefore, we formalize the second hypothesis by adopting a dichotomous classification of countries into Anglo-Saxon and European Continental following prior studies, in particular, Nobes (2011). In short, there is no consensus regarding the impact of institutional factors on the association between country and expected accounting practice. Regarding legal origin, Anglo-Saxon countries are expected to apply more conservative accounting practices, conversely taking into account the financing system and accounting values, continental European countries are expected to be more accounting conservative. We formalize our second hypothesis based on the above arguments and on the evidence that debt markets, either bank debt or bonds, exert the primary influence on the use of accounting conservatism (Ball et al., 2008). Given the importance of bank financing in continental Europe we posit the hypothesis:

$\mathrm{H} 2$ : Continental European countries exhibit a more conservative accounting practice than the Anglo- Saxon countries. 
Besides institutional factors, accountings standards, specifically IFRS, play a fundamental role in explaining accounting practice. The development of IFRS is driven by the need for accounting harmonization in response to the globalization of capital markets, firms' operations in different countries worldwide, increased cross-listings of firms and, in the case of European Union, the process of economic integration (Fearnley and Gray, 2015; Choi and Meek, 2011 and Ball, 2006). This harmonization aims to reduce disclosure and information processing costs relating to the increasing need of financial statement users to compare the information of firms from different countries (Choi and Meek, 2011 and Ball, 2006).

This harmonization through the adoption of IFRS is expected to influence the level of conservatism in accounting practice. Specifically, the IASB/FASB conceptual framework states that conservatism is not a conceptually desirable property of financial statements (Barker and McGeachin, 2015). In line with this position, Nobes (1998) argues that the IAS and the UK GAAP should be included in the Anglo-Saxon group (Class A), where outsiders require more public disclosure of timely information, both about losses and gains. This argument does not support an asymmetric recognition of losses and gains required by a conservative approach. Such an argument also applies to IFRS that have common features with the Anglo-Saxon model, (Borker, 2013 and Fearnley and Gray, 2015). The above studies have a similar position regarding conservatism to that reported by Gray (1988) that includes the Anglo-Saxon culture in a group that ranks high in terms of optimism accounting value, which is not consistent with losses being recognized in a timelier fashion than gains.

Opposite to the suggested in the IASB conceptual framework, the study of Barker and McGeachin (2015) analyses the content of international accounting standards themselves to understand if conservatism is present in the requirements of accounting standards. These authors identify a number of recognition, measurement, and presentation/disclosure requirements that lead to conservatism, and their findings support the evidence provided in some empirical literature that accounting is in practice conservative. A similar position is expressed by Andre et al. (2015), who argue that IFRS are conceptually conditionally conservative. However, these authors empirically find a decline in conditional conservatism after the adoption of IFRS, and they justify such a decrease with the misapplication of IFRS.

Additionally, the results reported in the empirical study of Barth, Landsman, and Lang (2008) are consistent with increased timely loss recognition after the adoption of IAS.

To further develop this analysis on the relationship between IFRS and accounting conservatism, it is important to account for a number of features relating to the flexibility allowed by IFRS. Nobes (2006) reports a number of reasons for the survival of differences in accounting practice under IFRS. For example, many options available that allow alternative accounting treatments, standards based on principles rather than rules may lead to different interpretations and the frequent use of estimates that can be biased differently across countries. Such flexibility allows the survival of national patterns within IFRS, as documented by Kvaal and Nobes (2010) and Ball (2006).

Overall, we have to analyse the interaction between a traditional conservative accounting practice, the flexibility provided by IFRS that would allow to continue part of the national accounting patterns and the majority of studies documenting that IFRS 
do not support an asymmetric recognition of losses relative to gains. This allows us to anticipate a decrease in the level of conservatism after the adoption of IFRS, and we formalize our third hypothesis:

H3: The level of conservatism decreases after the mandatory adoption of IFRS.

We further develop our research by examining if IFRS allow to adjust the level of conservatism in periods of economic downturn. This study maters, namely because during relevant financial crisis firms are negatively affected in their performance and, due to the contagion effect, such performance tends to spread to other firms and to real economic activities (Gunn et al., 2018 and Balakrishnan et al., 2016).

However, there is no consensus in existing research on whether economic downturns are associated with an increase or decrease in accounting conservatism. For example, Jenkins et al. (2009) demonstrate that management and auditors tend to report more conservative earnings during periods of economic recession than during economic expansions. Such conservative reporting would be demanded to minimise information asymmetry between management and outside stakeholders.

Another view is reported by Vichitsarawong et al. (2010) that examine conservatism surrounding the 1997 Asian crisis and find that conservatism tends to be low during the crisis. However, the authors also report that conservatism improves in the post-crisis after the implementation of corporate governance measures in the four Asian countries being analysed. In the same vein, Sodan et al. (2013) investigate conservatism in a sample of listed companies from Central and Eastern Europe and find empirical evidence that the level of conservatism is even lower during the 2007/08 financial crisis than before the crisis.

We argue that to understand management decisions regarding conservatism, we must account for two stages in the development of the crisis. The rationale behind our approach is that at the point when managers make their accounting choices, they decide on the basis of their expectations about the severity of the crisis. At the onset of the crisis, it is likely that they have incentives to avoid reporting negative news to outsiders in the hope that the market recovers. This attitude would result in a decrease in conservatism. However, with time the uncertainty about the severity of the crisis vanishes, and managers tend to change to a more conservative reporting. Such change may occur if managers are aware that accounting conservatism plays a role to stabilize financial systems, helps distressed firms to obtain funds, and represents an effective corporate governance mechanism.

If our arguments about the opposite signs of the impacts on conservatism over the subperiods are correct, then the impact of the crisis on conservatism over the entire period surrounding the crisis can be positive or negative or even no significant.

To capture the changes in conservatism surrounding the 2007/08 financial crisis, we consider the period of four years (pre and crisis) from 2005 to 2008 and the period from 2009 to 2012 (post-crisis). Based on the above arguments, accounting conservatism is expected to decrease during the pre and crisis period and an increase in the post-crisis period, and we formalise the following hypothesis:

H4: The level of conservatism reflects changes in economic conditions. 
To test the above hypothesis, we split this hypothesis into two:

H4.a): The level of conservative accounting practice is lower in the pre and crisis period during the 2007/08 financial crisis, under IFRS;

H4.b): The level of conservative accounting practice is higher in the period post the 2007/08 financial crisis under IFRS.

In the development of the above research hypothesis we propose that the impact of the crisis on conservatism should be investigated considering two periods, the pre and crisis period and the post-crisis period. This approach may explain mixed results when analysing the whole period surrounding the financial crisis because the effects on conservatism in each of the sub-periods are expected to have opposite signs.

Another likely implication is that the impact of the crisis on conservatism may vary from one country to another. For example, some countries failed to meet the criteria concerning national debt, budget deficit, inflation, and interest rates before and by the time of the crisis. Thus, firms in those countries were likely to have a higher exposure to economic decline and financing constraints. However, we must emphasise that our approach is oriented to an analysis by group of countries with similar characteristics and not to explain the effect at the country level using country-specific explanatory variables.

In addition, to deepen the analysis of the association between economic conditions and conservatism we must account for the severity of the crisis building on the finding of Trombetta and Imperatore (2014) that report an impact of business cycles on earnings management that depends on the intensity of the crisis. While we are not studying earnings management, their study is also related to financial reporting decisions. In a similar vein, Francis et al. (2013) find that the manipulation of earnings becomes more severe during the financial crisis and that firms following more conservative practices are better prepared to deal with economic recessions, particularly in more severe economic declines.

Therefore, we expect that the impact of the financial crisis on the level of accounting conservatism depends on the intensity of the crisis. To empirically capture such a nonmonotonic effect on conservatism, we use an approach that consists in selecting a group of countries that were more affected by the financial crisis. The worst affected European countries were the group of Southern countries (Greece, Portugal, and Spain) and Ireland, Verney (2009). We consider that firms in those countries were subject to more extreme conditions. We expect to find a stronger decline in conservatism during the pre and crisis period in the group of distressed countries. In addition, we expect to find a stronger increase in conservatism during the post-crisis period in the group of distressed countries, and we posit the following hypothesis,

H5: The impact of the financial crisis on conservatism is stronger for the group of distressed countries relative to the group of the remaining countries.

\section{Empirical research design}

Empirical research is developed on the basis of groups of countries that share some particular characteristic, and the main objective of this study is to investigate the effect 
of economic conditions on conditional conservatism. For that purpose, we use two subperiods, the sub-period from 2005 to 2008 and that from 2009 to 2012. Thus, we can say that financial statements in both sub-periods are prepared under the same accounting standards (IFRS). To ensure that all firms are reporting under the same standards, we collect a variable in Datastream known as "Accounting Standards Followed," and we only consider firms that follow IFRS. We are aware that some studies about IFRS adoption use more detailed criteria to control for the impact of accounting standards at the individual country level. For example, Andre et al. (2015) use an audit and enforcement index to study the impact of the adoption of conditional conservatism in individual European countries. Another example is the study of Othman and Kossentini (2015) that investigates IFRS adoption in 50 emerging economies using a proxy to measure the level of harmonization with IFRS. We follow a more standard approach (dummy variables) to identify the period after IFRS adoption and each one of the two sub-periods mentioned above. We expect that the impacts of economic changes in the two sub-periods have opposite signs. Therefore, the empirical research on the impact of IFRS adoption on conditional conservatism should control for the impact of the financial crisis.

In this section, we define the measures of conservatism used in this study, we specify the empirical models for testing the research hypotheses, and we describe the sample.

\section{Measures of conservatism}

The first measure of conservatism used in this study builds on the Basu (1997) model of asymmetric timeliness that reflects conditional conservatism. According to Basu, accounting practices are conservative when reported net income incorporates bad news more quickly than good news:

$$
\frac{X_{i t}}{P_{i, t-1}}=\beta_{0}+\beta_{1} D_{i t}+\beta_{2} R_{i t}+\beta_{3} D_{i t} R_{i t}+e_{i t}
$$

Where $\mathrm{X}$ is earnings per share, $\mathrm{P}$ is the stock price, $\mathrm{R}$ is stock return, and $\mathrm{D}$ is a dummy variable that is set to one, if the stock return is negative, and zero otherwise. The coefficient $\left(\beta_{2}\right)$ captures the timeliness of gain recognition, and a timely gain recognition implies this coefficient to be positive, $\left(\beta_{2}>0\right)$. In fact, the good news is measured by a positive stock return, and the good news is expected to increase earnings. In the case of negative stock returns, the dummy variable is one, so the coefficient that captures the timeliness of loss recognition is the sum $\left(\beta_{2}+\beta_{3}\right)$. Therefore, timely loss recognition implies $\left(\beta_{2}+\beta_{3}>0\right)$, because bad news is represented by a negative stock return and are expected to reduce earnings. When bad news is recognized in a timelier fashion than good news the coefficient $\left(\beta_{3}>0\right)$.

The second measure of conditional conservatism is a specification of the Basu (1997) model, as developed by Ball and Shivakumar (2005). This specification only requires accounting measures. This model regresses the change in net income in the current period on the change in net income in the prior period, a dummy that accounts for the negative change in net income in the prior period and an interaction term given by the dummy times change in net income in the prior period, 


$$
\Delta N I_{i, t}=\beta_{0}+\beta_{1} D \Delta N I_{i, t-1}+\beta_{2} \Delta N I_{i, t-1}+\beta_{3} D \Delta N I_{i, t-1} * \Delta N I_{i, t-1}+\varepsilon_{i, t}
$$

Where $(\Delta N I)$ represents the change in net income scaled by the beginning of year total assets and $(D \Delta N I)$ is a dummy variable that takes the value one when the change in net income in the prior year is negative and zero otherwise. This specification assumes that timely recognition of gains reflected in a temporary increase in income tends to reverse in the following period, consistent with a negative coefficient, $\left(\beta_{2}<0\right)$. In the case of losses, the dummy variable $(D \Delta N I)$ is equal to one, so the coefficient that accounts for reversal is the sum $\left(\beta_{2}+\beta_{3}\right)$. Therefore, a timely loss recognition implies this sum to be negative $\left(\beta_{2}+\beta_{3}<0\right)$. Finally, if losses are recognized in a timer fashion than gains then $\left(\beta_{3}<0\right)$, and this last condition reflects a conservative accounting practice.

\section{Empirical models}

In our tests, besides the standard models defined above, we use modified versions to include specific periods within the sample period or specific groups of countries. We must emphasise that our approach is oriented to an analysis by groups of countries with similar characteristics and not to explain the effect at the country level using countryspecific explanatory variables. The first type of the modified versions includes one additional dummy variable and the corresponding interaction terms with the remaining explanatory variables. In the examples below, we use the dummy (Angl) that represents Anglo-Saxon countries. We also use this type of models to capture the impact of IFRS adoption (dummy IFRS instead of Angl) and to capture the effect of economic conditions (dummy Econ instead of Angl). In addition, the dummy (Econ) alternates between representing the pre and crisis period and the post-crisis period.

The modified version of the Basu (1997) model is,

$$
\begin{gathered}
\frac{X_{i t}}{P_{i, t-1}}=\beta_{0}+\beta_{1} D_{i t}+\beta_{2} R_{i t}+\beta_{3} D_{i t} * R_{i t}+\beta_{4} A n g l+\beta_{5} \text { Angl } * D_{i t}+\beta_{6} A n g l * R_{i t} \\
+\beta_{7} A n g l * D_{i t} * R_{i t}+e_{i t}
\end{gathered}
$$

In the case of the modified Ball and Shivakumar (2005) model, the regression is:

$$
\begin{aligned}
& \Delta N I_{i, t}=\beta_{0}+\beta_{1} D \Delta N I_{i, t-1}+\beta_{2} \Delta N I_{i, t-1}+\beta_{3} D \Delta N I_{i, t-1} * \Delta N I_{i, t-1}+\beta_{4} \text { Angl }+ \\
& \beta_{5} \text { Angl } * D \Delta N I_{i, t-1}+\beta_{6} \text { Angl } * \Delta N I_{i, t-1}+\beta_{7} \text { Angl } * D \Delta N I_{i, t-1} * \Delta N I_{i, t-1}+\varepsilon_{i, t},
\end{aligned}
$$

where the variables have already been described above.

In the second type of model, we include two additional dummy variables in the original model. For example, to test the effect of the intensity of the crisis on conservatism, besides the dummy that accounts for economic conditions (Econ) we need a dummy to identify more distressed countries (Distr). This model allows to test if there are different impacts on distressed countries. The dummy (Econ) alternates between representing the pre and crisis period and the post-crisis period. 
The second type of modified Basu (1997) model is,

$$
\begin{aligned}
& \frac{X_{i t}}{P_{i, t-1}}=\beta_{0}+\beta_{1} D_{i t} \\
&+\beta_{2} R_{i t}+\beta_{3} D_{i t} * R_{i t}+\beta_{4} E \operatorname{con}+\beta_{5} \text { Econ } * D_{i t}+\beta_{6} E \operatorname{con} * R_{i t} \\
&+\beta_{7} \text { Econ } * D_{i t} * R_{i t}+\beta_{8} \text { Distr }+\beta_{9} \text { Distr } * D_{i t}+\beta_{10} \text { Distr } * R_{i t} \\
&+\beta_{11} \text { Distr } * D_{i t} * R_{i t}+\beta_{12} \text { Distr } * \text { Econ }+\beta_{13} \text { Distr } * \text { Econ } * D_{i t} \\
&+\beta_{14} \text { Distr } * \text { Econ } * R_{i t}+\beta_{15} \text { Distr } * \text { Econ } * D_{i t} * R_{i t}+e_{i t}
\end{aligned}
$$

The second type of modified Ball and Shivakumar (2005) model is:

$$
\begin{aligned}
& \Delta N I_{i, t}=\beta_{0}+\beta_{1} D \Delta N I_{i, t-1}+\beta_{2} \Delta N I_{i, t-1}+\beta_{3} D \Delta N I_{i, t-1} * \Delta N I_{i, t-1}+\beta_{4} E c o n+ \\
& \beta_{5} \text { Econ } * D \Delta N I_{i, t-1}+\beta_{6} \text { Econ } * \Delta N I_{i, t-1}+\beta_{7} \text { Econ } * D \Delta N I_{i, t-1} * \Delta N I_{i, t-1}+ \\
& \beta_{8} \text { Distr }+\beta_{9} \text { Distr } * D \Delta N I_{i, t-1}+\beta_{10} \text { Distr } * \Delta N I_{i, t-1}+\beta_{11} \text { Distr } * D \Delta N I_{i, t-1} * \\
& \Delta N I_{i, t-1}+\beta_{12} \text { Distr } * \text { Econ }+\beta_{13} \text { Distr } * \text { Econ } * D \Delta N I_{i, t-1}+\beta_{14} \text { Distr } * \text { Econ } * \\
& \Delta N I_{i, t-1}+\beta_{15} \text { Distr } * \text { Econ } * D \Delta N I_{i, t-1} * \Delta N I_{i, t-1}+\varepsilon_{i, t},
\end{aligned}
$$

where the variables have already been described above.

\section{Data and sample selection}

Our sample consists of European firms listed on the most representative stock exchange in each country. In the case of cross-listed firms, each firm is only considered in the domestic stock exchange. Data was collected from Datastream over the period from 1998 to 2018 .

The initial sample consists of 10,705 firms from 17 European countries as reports in Table 1. Then we exclude financial firms, SIC code from 6000 to 6999 , and firms with less than seven years with complete data on the series of variables used in this study. After the selection procedure, there are 4,839 firms remaining.

To minimize potential bias in estimations due to the influence of extreme outliers, we winsorize the continuous variables of interest at the 1st and 99th percentiles.

The three most representative countries $(59 \%)$ in the sample are the UK $(31 \%)$, France $(16 \%)$ and Germany $(12 \%)$. 


\section{Table 1. Sample by Country}

This table provides a breakdown of the sample by country. The table reports the number of firms in the initial sample and the number of firms after excluding financial firms, SIC code from 6000 to 6999 , and excluding firms with less than seven years with complete data on the series of variables used in this study (final sample).

\begin{tabular}{lcc}
\hline Country & Initial sample & Final sample \\
\hline Austria & 160 & 64 \\
Belgium & 229 & 107 \\
Czech Republic & 89 & 29 \\
Denmark & 290 & 130 \\
Finland & 244 & 124 \\
France & 1,572 & 768 \\
Germany & 1,115 & 590 \\
Greece & 389 & 288 \\
Ireland & 76 & 35 \\
Italy & 542 & 238 \\
Netherlands & 267 & 116 \\
Norway & 483 & 195 \\
Portugal & 131 & 59 \\
Spain & 309 & 121 \\
Sweden & 971 & 389 \\
Switzerland & 163 & 105 \\
United Kingdom & 3,675 & 1481 \\
Pool & $\mathbf{1 0 , 7 0 5}$ & $\mathbf{4 , 8 3 9}$ \\
\hline Source: & & \\
\hline
\end{tabular}

Source: Authors 


\section{Empirical results}

The descriptive statistics of the main variables of our study are provided in Table 2 . These variables are used to estimate the regressions of Basu (1997) and Ball and Shivakumar (2005).

\section{Table 2. Descriptive statistics}

This table reports some descriptive statistics, namely median, standard deviation, first and third quartiles, for the continuous variables used in the regressions of Basu (1997) and Ball and Shivakumar (2005) for the seventeen European countries, over the sample period from 1998 to 2018. Given that all continuous variables are winsorized at the 1st and 99th percentiles, we do not report the minimum and maximum values.

\begin{tabular}{lccccccc}
\hline Country & Obs & \multicolumn{2}{c}{ EPS/price } & \multicolumn{2}{c}{ Stock return } & \multicolumn{2}{c}{ ChgNetInc/Assets } \\
& & Med/Std & Q1/Q3 & Med/Std & Q1/Q3 & Med/Std & Q1/Q3 \\
\hline Pool & 66,811 & $0.04 / 0.30$ & $-0.04 / 0.08$ & $0.003 / 0.59$ & $-0.26 / 0.29$ & $0.005 / 0.19$ & $-0.02 / 0.03$ \\
Austria & 935 & $0.06 / 0.22$ & $0.02 / 0.10$ & $0.03 / 0.47$ & $-0.17 / 0.29$ & $0.004 / 0.15$ & $-0.01 / 0.02$ \\
Belgium & 1,578 & $0.06 / 0.23$ & $0.01 / 0.09$ & $0.03 / 0.47$ & $-0.19 / 0.26$ & $0.004 / 0.14$ & $-0.02 / 0.03$ \\
Czech Rep & 291 & $0.09 / 0.32$ & $0.06 / 0.15$ & $0.07 / 0.40$ & $-0.07 / 0.31$ & $0.004 / 0.10$ & $-0.01 / 0.02$ \\
Denmark & 1,946 & $0.04 / 0.28$ & $-0.02 / 0.09$ & $0.03 / 0.54$ & $-0.24 / 0.34$ & $0.005 / 0.18$ & $-0.03 / 0.04$ \\
Finland & 2,046 & $0.05 / 0.20$ & $0.002 / 0.09$ & $0.04 / 0.48$ & $-0.22 / 0.29$ & $0.005 / 0.12$ & $-0.03 / 0.04$ \\
France & 10,723 & $0.05 / 0.25$ & $-0.01 / 0.09$ & $0.02 / 0.53$ & $-0.22 / 0.27$ & $0.004 / 0.14$ & $-0.02 / 0.03$ \\
Germany & 8,289 & $0.04 / 0.28$ & $-0.03 / 0.08$ & $0.01 / 0.57$ & $-0.24 / 0.31$ & $0.005 / 0.19$ & $-0.03 / 0.04$ \\
Greece & 4,171 & $0.02 / 0.49$ & $-0.09 / 0.07$ & $-0.10 / 0.74$ & $-0.40 / 0.24$ & $0.001 / 0.10$ & $-0.02 / 0.02$ \\
Ireland & 497 & $0.05 / 0.29$ & $-0.04 / 0.10$ & $0.06 / 0.57$ & $-0.25 / 0.34$ & $0.008 / 0.16$ & $-0.02 / 0.04$ \\
Italy & 3,381 & $0.04 / 0.27$ & $-0.03 / 0.07$ & $-0.02 / 0.46$ & $-0.25 / 0.23$ & $0.002 / 0.11$ & $-0.02 / 0.02$ \\
Netherlands & 1,800 & $0.06 / 0.24$ & $0.01 / 0.09$ & $0.02 / 0.49$ & $-0.20 / 0.28$ & $0.006 / 0.18$ & $-0.02 / 0.03$ \\
Norway & 2,475 & $0.03 / 0.38$ & $-0.10 / 0.10$ & $0.01 / 0.70$ & $-0.32 / 0.36$ & $0.005 / 0.21$ & $-0.05 / 0.06$ \\
Portugal & 899 & $0.05 / 0.46$ & $-0.04 / 0.11$ & $-0.03 / 0.51$ & $-0.26 / 0.22$ & $0.002 / 0.12$ & $-0.01 / 0.02$ \\
Spain & 1,818 & $0.05 / 0.30$ & $0.01 / 0.09$ & $0.01 / 0.49$ & $-0.22 / 0.26$ & $0.003 / 0.13$ & $-0.02 / 0.02$ \\
Sweden & 5,081 & $0.04 / 0.27$ & $-0.07 / 0.08$ & $0.01 / 0.62$ & $-0.29 / 0.34$ & $0.01 / 0.22$ & $-0.04 / 0.05$ \\
Switzerland & 1,883 & $0.05 / 0.13$ & $0.03 / 0.08$ & $0.06 / 0.43$ & $-0.14 / 0.28$ & $0.01 / 0.12$ & $-0.01 / 0.03$ \\
UK & 18,998 & $0.03 / 0.29$ & $-0.08 / 0.08$ & $-0.002 / 0.64$ & $-0,31 / 0.31$ & $0.01 / 0.24$ & $-0.04 / 0.05$ \\
\hline Source: $A$ then & & & & & & &
\end{tabular}

Source: Authors

The number of observations is substantially larger for the UK, reflecting the dimension of the respective stock market, France and Germany follow. Over the entire sample period, the median earnings per share are positive for all countries. Regarding the performance of equity markets, as measured by stock return, the median return is positive for the majority of countries, except in the case of four countries. In addition, in the case of the distribution of stock returns, the first quartile tends to be negative, but the third quartile is always positive. Those statistics are likely to reflect a considerable level of integration of markets across European countries. 


\section{Regression analysis}

In this part of the section of empirical results, we provide the estimated coefficients of a number of regressions. We begin with the test of conservative accounting practice in European countries and after we compare conservatism across specific groups of countries. In addition, we analyse the impact of IFRS adoption on conservatism, followed by the analysis of how changes in economic conditions affect conservatism. In the last test, we investigate whether the impact depends on the intensity of changes in economic conditions.

\section{Testing conservative accounting practice}

We use a panel data structure to estimate the level of conditional conservatism in European countries. For the entire sample period and using the original Basu regression for the pool of countries, we perform tests for heteroscedasticity and autocorrelation. With the heteroscedasticity White test, we find an F-statistic (211.12), p-value (0.00). The null hypothesis for the White test is homoscedasticity, so we reject the null hypothesis and assume heteroscedasticity. Furthermore, using the same regression, we find a Durbin-Watson statistic $1.26(<2)$, consistent with a positive serial correlation. Therefore, using the Eviews software, we estimate our models with a feasible GLS with period seemingly unrelated regression (SUR) that can achieve asymptotically efficient estimates (Baltagi, 2005). We select the option period SUR that allows for both heteroscedasticity and serial correlation.

For each country, we estimate the Basu (1997) linear regression of earnings per share on stock return and the Ball and Shivakumar (2005) linear regression of the change in net income on the change in net income in the prior period. Table 3 displays the results of the estimations for each country and for the pool of countries.

Panel A shows the results for the Basu (1997) model. Regarding the timely recognition of gains, the coefficient of interest is $\left(\beta_{2}\right)$, which captures the sensitivity of earnings to the good news. When this coefficient is positive and significant indicates timely gain recognition. The timeliness of loss recognition is measured by $\left(\beta_{2}+\beta_{3}\right)$, which measures the sensitivity of earnings to bad news, and when this sum is positive and significant, indicates timely loss recognition. The Wald test is used to test the joint significance of the sum of the two coefficients. The coefficient of interest regarding the detection of conservatism is that of the interaction term $\left(\beta_{3}\right)$ that is positive when earnings are more sensitive to bad news than to good news.

Panel B shows the results of the estimations for the Ball and Shivakumar (2005) regressions. A timely recognition of economic gains means they are recognized as transitory increases in income, and thus they tend to reverse in the next period, implying $\left(\beta_{2}<0\right)$. This specification assumes that timely recognition of losses reflected in a temporary decrease in income tends to reverse in the following period. This reversion is captured by a negative value of $\left(\beta_{2}+\beta_{3}<0\right)$. If income is timelier in reflecting bad news than good news then $\left(\beta_{3}<0\right)$. 
Table 3. Accounting conservatism in Europe

This table reports the results for the regressions of Basu (1997) and Ball and Shivakumar (2005) for European countries using the sample period from 1998 to 2018. The Basu (1997) model is,

$$
\frac{X_{i t}}{P_{i, t-1}}=\beta_{0}+\beta_{1} D_{i t}+\beta_{2} R_{i t}+\beta_{3} D_{i t} * R_{i t}+e_{i t}
$$

Where $\mathrm{X}$ is earnings per share, $\mathrm{P}$ is the stock price, $\mathrm{R}$ is stock return, and $\mathrm{D}$ is a dummy variable that is set to one if the stock return is negative and zero otherwise.

The Ball and Shivakumar (2005) model is,

$$
\Delta N I_{i, t}=\beta_{0}+\beta_{1} D \Delta N I_{i, t-1}+\beta_{2} \Delta N I_{i, t-1}+\beta_{3} D \Delta N I_{i, t-1} * \Delta N I_{i, t-1}+\varepsilon_{i, t}
$$

Where $(\Delta N I)$ represents the change in net income scaled by the beginning of year total assets and $(D \Delta N I)$ is a dummy variable that takes the value one when the change in net income in the prior year is negative and zero otherwise. All continuous variables are winsorized at the 1st and 99th percentiles.

Notes: ***, **, * indicate significance at the 1 percent, 5 percent, and 10 percent levels, respectively. t-statistics are presented in parentheses.

\begin{tabular}{|c|c|c|c|c|c|}
\hline & $\beta_{0}$ & $\beta_{1}$ & $\beta_{2}$ & $\beta_{3}$ & $\beta_{2}+\beta_{3}$ \\
\hline Pool & $\begin{array}{c}0.055 * * * \\
(83.647)\end{array}$ & $\begin{array}{c}-0.003 * * * \\
(-3.045)\end{array}$ & $\begin{array}{c}0.007 * * * \\
(5.724)\end{array}$ & $\begin{array}{l}0.184 * * * \\
(56.684)\end{array}$ & $0.191 * * *$ \\
\hline Num. Observ. & 66,811 & & & & \\
\hline Adjusted R-squa. & 0.110 & & & & \\
\hline Austria & $\begin{array}{c}0.056 * * * \\
(15.330)\end{array}$ & $\begin{array}{c}-0.008 \\
(-1,380)\end{array}$ & $\begin{array}{c}0.047 * * * \\
(5.547)\end{array}$ & $\begin{array}{c}0.061 * * * \\
(3.009)\end{array}$ & $\begin{array}{c}0.108 * * * \\
(5.870)\end{array}$ \\
\hline Num. Obs. & 935 & & & & \\
\hline Adjusted R-squa. & 0.145 & & & & \\
\hline Belgium & $\begin{array}{c}0.055^{*} * * \\
(18.686)\end{array}$ & $\begin{array}{c}0.006 \\
(1.198)\end{array}$ & $\begin{array}{c}0.052 * * * \\
(6.641)\end{array}$ & $\begin{array}{c}0.101 * * * \\
(5.599)\end{array}$ & $\begin{array}{c}0.153 * * * \\
(9.406)\end{array}$ \\
\hline Num. Obs & 1,578 & & & & \\
\hline Adjusted R-squa. & 0.133 & & & & \\
\hline Czech Rep & $\begin{array}{c}0.065^{* * *} \\
(11.145)\end{array}$ & $\begin{array}{c}0.028 * * * \\
(2.631)\end{array}$ & $\begin{array}{l}0.028^{*} \\
(1.869)\end{array}$ & $\begin{array}{c}0.103 * * \\
(1.954)\end{array}$ & $\begin{array}{c}0.131 * * * \\
(2.579)\end{array}$ \\
\hline Num. Obs & 291 & & & & \\
\hline Adjusted R-squa. & 0.025 & & & & \\
\hline Denmark & $\begin{array}{c}0.044 * * * \\
(12.406)\end{array}$ & $\begin{array}{c}0.013 * * \\
(1.921)\end{array}$ & $\begin{array}{c}0.043^{* * *} * \\
(6.220)\end{array}$ & $\begin{array}{c}0.183 * * * \\
(8.885)\end{array}$ & $\begin{array}{c}0.226^{* * * *} \\
(11.615)\end{array}$ \\
\hline Num. Obs & 1,946 & & & & \\
\hline Adjusted R-squa. & 0.141 & & & & \\
\hline Finland & $\begin{array}{c}0.056^{* * * *} \\
(19.820)\end{array}$ & $\begin{array}{c}-0.001 \\
(-0.168)\end{array}$ & $\begin{array}{c}0.042 * * * \\
(6.728)\end{array}$ & $\begin{array}{c}0.078 * * * \\
(5.324)\end{array}$ & $\begin{array}{c}0.120 * * * \\
(9.025)\end{array}$ \\
\hline Num. Obs & 2,046 & & & & \\
\hline Adjusted R-squa. & 0.127 & & & & \\
\hline France & $\begin{array}{c}0.054 * * * \\
(43.998)\end{array}$ & $\begin{array}{c}-0.003 \\
(-1.158)\end{array}$ & $\begin{array}{c}0.024 * * * \\
(9.252)\end{array}$ & $\begin{array}{c}0.119 * * * \\
(16.830)\end{array}$ & $\begin{array}{c}0.143 * * * \\
(21.837)\end{array}$ \\
\hline Num. Obs & 10,723 & & & & \\
\hline Adjusted R-squa. & 0.104 & & & & \\
\hline
\end{tabular}

\section{Panel A: Basu Model}




$\begin{array}{cccccc}\text { Germany } & 0.050 * * * & -0.003 & 0.015 * * * & 0.166 * * * & 0.181 * * * \\ & (28.637) & (-0.954) & (4.350) & (18.568) & (21.855)\end{array}$

Num. Obs $\quad 8,289$

Adjusted R-squa. $\quad 0.109$

\begin{tabular}{|c|c|c|c|c|c|}
\hline Greece & $\begin{array}{c}0.005 \\
(0.776)\end{array}$ & $\begin{array}{c}-0.007 \\
(-0.740)\end{array}$ & $\begin{array}{c}0.016^{* *} \\
(2.358)\end{array}$ & $\begin{array}{c}0.100 * * * \\
(4.885)\end{array}$ & $\begin{array}{c}0.116^{* * *} \\
(6.045)\end{array}$ \\
\hline Num. Obs & 4,171 & & & & \\
\hline Adjusted R-squa. & 0.025 & & & & \\
\hline Ireland & $\begin{array}{c}0.059 * * * \\
(7.002)\end{array}$ & $\begin{array}{c}-0.003 \\
(-0.205)\end{array}$ & $\begin{array}{l}0.015 \\
(0.968)\end{array}$ & $\begin{array}{c}0.155^{* * *} \\
(3.946)\end{array}$ & $\begin{array}{c}0.170^{* * * *} \\
(4.692)\end{array}$ \\
\hline Num. Obs & 497 & & & & \\
\hline Adjusted R-squa. & 0.095 & & & & \\
\hline Italy & $\begin{array}{r}0.038 * * * \\
(12.807)\end{array}$ & $\begin{array}{c}-0.006 \\
(-1.353)\end{array}$ & $\begin{array}{c}0.035 * * * \\
(5.572)\end{array}$ & $\begin{array}{c}0.081 * * * \\
(5.545)\end{array}$ & $\begin{array}{c}0.116^{* * * *} \\
(8.747)\end{array}$ \\
\hline $\begin{array}{l}\text { Num. Obs } \\
\text { Adjusted R-squa. }\end{array}$ & $\begin{array}{l}3,381 \\
0.076\end{array}$ & & & & \\
\hline Netherlands & $\begin{array}{r}0.074 * * * \\
(21.829)\end{array}$ & $\begin{array}{l}-0.012 * * \\
(-2.197)\end{array}$ & $\begin{array}{c}-0.001 \\
(-0.031)\end{array}$ & $\begin{array}{c}0.172 * * * \\
(9.708)\end{array}$ & $\begin{array}{l}0.173 * * * \\
(10.852)\end{array}$ \\
\hline $\begin{array}{l}\text { Num. Obs } \\
\text { Adjusted R-squa. }\end{array}$ & $\begin{array}{l}1,800 \\
0.130\end{array}$ & & & & \\
\hline Norway & $\begin{array}{c}0.053 * * * \\
(9.728)\end{array}$ & $\begin{array}{l}-0.005 \\
(-0.592)\end{array}$ & $\begin{array}{l}0.013^{*} \\
(1.894)\end{array}$ & $\begin{array}{l}0.253 * * * \\
(11.567)\end{array}$ & $\begin{array}{l}0.266^{* * * *} \\
(12.863)\end{array}$ \\
\hline $\begin{array}{l}\text { Num. Obs } \\
\text { Adjusted R-squa. }\end{array}$ & $\begin{array}{l}2,475 \\
0.129\end{array}$ & & & & \\
\hline Portugal & $\begin{array}{c}0.070 * * * \\
(7.097)\end{array}$ & $\begin{array}{c}0.009 \\
(0.558)\end{array}$ & $\begin{array}{c}0.014 \\
(0.646)\end{array}$ & $\begin{array}{c}0.247 * * * \\
(5.227)\end{array}$ & $\begin{array}{c}0.261 * * * \\
(6.203)\end{array}$ \\
\hline $\begin{array}{l}\text { Num. Obs } \\
\text { Adjusted R-squa. }\end{array}$ & $\begin{array}{l}899 \\
0.063 \\
\end{array}$ & & & & \\
\hline Spain & $\begin{array}{r}0.058 * * * \\
(16.283)\end{array}$ & $\begin{array}{c}-0.003 \\
(-0.575)\end{array}$ & $\begin{array}{c}0.009 \\
(1.221)\end{array}$ & $\begin{array}{c}0.130 * * * \\
(6.573)\end{array}$ & $\begin{array}{c}0.139 * * * \\
(6.203)\end{array}$ \\
\hline $\begin{array}{l}\text { Num. Obs } \\
\text { Adjusted R-squa. }\end{array}$ & $\begin{array}{l}1,818 \\
0.062\end{array}$ & & & & \\
\hline Sweden & $\begin{array}{c}0.052 * * * \\
(20.339)\end{array}$ & $\begin{array}{l}0.008 * \\
(1.710)\end{array}$ & $\begin{array}{c}0.013 * * * \\
(3.190)\end{array}$ & $\begin{array}{l}0.230 * * * \\
(19.175)\end{array}$ & $\begin{array}{l}0.243 * * * \\
(21.473)\end{array}$ \\
\hline $\begin{array}{l}\text { Num. Obs } \\
\text { Adjusted R-squa. }\end{array}$ & $\begin{array}{l}5,081 \\
0.144\end{array}$ & & & & \\
\hline Switzerland & $\begin{array}{r}0.053 * * * \\
(34.037)\end{array}$ & $\begin{array}{c}-0.001 \\
(-0.455)\end{array}$ & $\begin{array}{c}0.027 * * * \\
(7.410)\end{array}$ & $\begin{array}{c}0.071^{* * * *} \\
(6.861)\end{array}$ & $\begin{array}{c}0.098 * * * \\
(10.181)\end{array}$ \\
\hline $\begin{array}{l}\text { Num. Obs } \\
\text { Adjusted R-squa. }\end{array}$ & $\begin{array}{l}1,883 \\
0.157 \\
\end{array}$ & & & & \\
\hline UK & $\begin{array}{c}0.060 * * * \\
(42.076)\end{array}$ & $\begin{array}{c}-0.008 * * * \\
(-3.198)\end{array}$ & $\begin{array}{c}-0.022 * * * \\
(-9.246)\end{array}$ & $\begin{array}{l}0.249 * * * \\
(39.015)\end{array}$ & $\begin{array}{l}0.227 * * * \\
(34.300)\end{array}$ \\
\hline $\begin{array}{l}\text { Num. Obs } \\
\text { Adjusted R-squa. }\end{array}$ & $\begin{array}{l}18,998 \\
0.129\end{array}$ & & & & \\
\hline
\end{tabular}


Panel B: Ball and Shivakumar Model

\begin{tabular}{|c|c|c|c|c|c|}
\hline & $\boldsymbol{\beta}_{0}$ & $\beta_{1}$ & $\beta_{2}$ & $\boldsymbol{\beta}_{3}$ & $\beta_{2}+\beta_{3}$ \\
\hline Pool & $\begin{array}{c}0.003 * * * \\
(16636)\end{array}$ & $\begin{array}{l}-0.007 * * * \\
(-21706)\end{array}$ & $-0.057 * * *$ & $-0.444 * * *$ & $-0.501 * * *$ \\
\hline Num. Obs. & 62,740 & & & & \\
\hline Adjusted R-squa. & 0.084 & & & & \\
\hline Austria & $\begin{array}{c}0.004 * * * \\
(3.439)\end{array}$ & $\begin{array}{c}-0.015 * * * \\
(-6.948)\end{array}$ & $\begin{array}{c}-0.108 * * * \\
(-2.690)\end{array}$ & $\begin{array}{c}-0.792 * * * \\
(-10.482)\end{array}$ & $\begin{array}{c}-0.899 * * * \\
(-14.054)\end{array}$ \\
\hline Num. Obs. & 886 & & & & \\
\hline Adjusted R-squa. & 0.188 & & & & \\
\hline Belgium & $\begin{array}{c}0.003 * \\
(2.371)\end{array}$ & $\begin{array}{c}-0.003 \\
(-1.447)\end{array}$ & $\begin{array}{c}-0.162 * * * \\
(-4.664)\end{array}$ & $\begin{array}{c}-0.304 * * * \\
(-5.622)\end{array}$ & $\begin{array}{c}-0.466 * * * \\
(-11.233)\end{array}$ \\
\hline Num. Obs & 1482 & & & & \\
\hline Adjusted R-squa. & 0.108 & & & & \\
\hline Czech Rep & $\begin{array}{c}0.003 \\
(1.461)\end{array}$ & $\begin{array}{l}-0.006 * \\
(-1.653)\end{array}$ & $\begin{array}{c}-0.099 \\
(-1.148)\end{array}$ & $\begin{array}{c}-0.667 * * * \\
(-4.548)\end{array}$ & $\begin{array}{c}-0.766 \text { *** } \\
(-6.461)\end{array}$ \\
\hline Num. Obs & 259 & & & & \\
\hline Adjusted R-squa. & 0.147 & & & & \\
\hline Denmark & $\begin{array}{c}0.008 * * * \\
(5.656)\end{array}$ & $\begin{array}{c}-0.019 * * * \\
(-7.603)\end{array}$ & $\begin{array}{c}-0.114 * * * \\
(-3.743)\end{array}$ & $\begin{array}{c}-0.593 * * * \\
(-10.793)\end{array}$ & $\begin{array}{c}-0.707 * * * \\
(-15.433)\end{array}$ \\
\hline Num. Obs & 1,839 & & & & \\
\hline Adjusted R-squa. & 0.120 & & & & \\
\hline Finland & $\begin{array}{c}0.001 \\
(0.293)\end{array}$ & $\begin{array}{c}-0.001 \\
(-0.292)\end{array}$ & $\begin{array}{c}-0.137 * * * \\
(-3.725)\end{array}$ & $\begin{array}{c}-0.241 * * * \\
(-4.295)\end{array}$ & $\begin{array}{c}-0.378 * * * \\
(-8.906)\end{array}$ \\
\hline Num. Obs & 1,955 & & & & \\
\hline Adjusted R-squa. & 0.068 & & & & \\
\hline France & $\begin{array}{c}0.002 * * * \\
(6,834\end{array}$ & $\begin{array}{c}-0.004 * * * \\
(-6.640)\end{array}$ & $\begin{array}{c}-0.032 * * * \\
(-2.592)\end{array}$ & $\begin{array}{c}-0.419 * * * \\
(-20.011)\end{array}$ & $\begin{array}{c}-0.451 * * * \\
(-26.773)\end{array}$ \\
\hline Num. Obs & 10,050 & & & & \\
\hline Adjusted R-squa. & 0.070 & & & & \\
\hline Germany & $\begin{array}{c}0.004 * * * \\
(7.325)\end{array}$ & $\begin{array}{c}-0.007 * * * \\
(-7.604)\end{array}$ & $\begin{array}{c}-0.057 * * * \\
(-4.206)\end{array}$ & $\begin{array}{c}-0.474 * * * \\
(-20.139)\end{array}$ & $\begin{array}{c}-0.531 * * * \\
(-27.689)\end{array}$ \\
\hline Num. Obs & 7,899 & & & & \\
\hline Adjusted R-squa. & 0.094 & & & & \\
\hline Greece & $\begin{array}{c}0.002 * * \\
(2.318)\end{array}$ & $\begin{array}{c}-0.010 * * * \\
(-7.650)\end{array}$ & $\begin{array}{c}-0.150 * * * \\
(-6.891)\end{array}$ & $\begin{array}{c}-0.319 * * * \\
(-8.564)\end{array}$ & $\begin{array}{c}-0.469 * * * \\
(-15.496)\end{array}$ \\
\hline Num. Obs & 3,857 & & & & \\
\hline Adjusted R-squa. & 0.071 & & & & \\
\hline Ireland & $\begin{array}{c}-0.003 \\
(-0.863)\end{array}$ & $\begin{array}{c}-0.001 \\
(-0.087)\end{array}$ & $\begin{array}{c}0.168 * * * \\
(3.572)\end{array}$ & $\begin{array}{c}-0.834 * * * \\
(-8.028)\end{array}$ & $\begin{array}{c}-0.666 * * * \\
(-7.190)\end{array}$ \\
\hline Num. Obs & 468 & & & & \\
\hline Adjusted R-squa. & 0.127 & & & & \\
\hline Italy & $\begin{array}{c}0.004 * * * \\
(6.895)\end{array}$ & $\begin{array}{c}-0.004 * * * \\
(-4.618)\end{array}$ & $\begin{array}{c}-0.103 * * * \\
(-4.951)\end{array}$ & $\begin{array}{c}-0.184 * * * \\
(-5.263)\end{array}$ & $\begin{array}{c}-0.287 * * * \\
(-10.243)\end{array}$ \\
\hline Num. Obs & 3,255 & & & & \\
\hline Adjusted R-squa. & 0.038 & & & & \\
\hline Netherlands & $\begin{array}{c}0.006^{* * *} \\
(4.437)\end{array}$ & $\begin{array}{c}-0.012 * * * \\
(-5.376)\end{array}$ & $\begin{array}{c}-0.134 * * * \\
(-3.921)\end{array}$ & $\begin{array}{c}-0.469 * * * \\
(-8.634)\end{array}$ & $\begin{array}{c}-0.603 * * * \\
(-14.281)\end{array}$ \\
\hline Num. Obs & 1,687 & & & & \\
\hline Adjusted R-squa. & 0.117 & & & & \\
\hline
\end{tabular}




\begin{tabular}{|c|c|c|c|c|c|}
\hline Norway & $\begin{array}{c}0.001 \\
(0.441)\end{array}$ & $\begin{array}{c}-0.004 \\
(-1.452)\end{array}$ & $\begin{array}{c}-0.029 \\
(-1.053)\end{array}$ & $\begin{array}{c}-0.480 * * * \\
(-10.031)\end{array}$ & $\begin{array}{c}-0.509 * * * \\
(-13.151)\end{array}$ \\
\hline Num. Obs & 2,343 & & & & \\
\hline Adjusted R-squa. & 0.079 & & & & \\
\hline Portugal & $\begin{array}{c}0.002 \\
(1.479)\end{array}$ & $\begin{array}{c}-0.008 * * * \\
(-3.047)\end{array}$ & $\begin{array}{l}-0.132 * * \\
(-2.504)\end{array}$ & $\begin{array}{c}-0.340 * * * \\
(-4.357)\end{array}$ & $\begin{array}{c}-0.472 * * * \\
(-8.239)\end{array}$ \\
\hline Num. Obs & 840 & & & & \\
\hline Adjusted R-squa. & 0.080 & & & & \\
\hline Spain & $\begin{array}{c}0.006 * * * \\
(7.632)\end{array}$ & $\begin{array}{c}-0.016^{* * * *} \\
(-9.122)\end{array}$ & $\begin{array}{c}-0.114 * * * \\
(-4.038)\end{array}$ & $\begin{array}{c}-0.546 * * * \\
(-9.769)\end{array}$ & $\begin{array}{c}-0.660 * * * \\
(-13.711)\end{array}$ \\
\hline Num. Obs & 1,726 & & & & \\
\hline Adjusted R-squa. & 0.105 & & & & \\
\hline Sweden & $\begin{array}{c}0.007 * * * \\
(6.483)\end{array}$ & $\begin{array}{c}-0.010 * * * \\
(-5.839)\end{array}$ & $\begin{array}{c}-0.053 * * * \\
(-2.947)\end{array}$ & $\begin{array}{c}-0.390 * * * \\
(-12.246)\end{array}$ & $\begin{array}{c}-0.443 * * * \\
(-16.895)\end{array}$ \\
\hline $\begin{array}{l}\text { Num. Obs } \\
\text { Adjusted R-squa. }\end{array}$ & $\begin{array}{l}4,784 \\
0.059 \\
\end{array}$ & & & & \\
\hline Switzerland & $\begin{array}{c}0.005 * * * \\
(5.463)\end{array}$ & $\begin{array}{c}-0.008 * * * \\
(-4.287)\end{array}$ & $\begin{array}{c}-0.105^{* * *} \\
(-3.118)\end{array}$ & $\begin{array}{c}-0.435^{* * * *} \\
(-7.926)\end{array}$ & $\begin{array}{c}-0.540 * * * \\
(-12.470)\end{array}$ \\
\hline $\begin{array}{l}\text { Num. Obs } \\
\text { Adjusted R-squa. }\end{array}$ & $\begin{array}{l}1,797 \\
0.088 \\
\end{array}$ & & & & \\
\hline UK & $\begin{array}{c}0.002 * * * \\
(4.208)\end{array}$ & $\begin{array}{c}-0.008 * * * \\
(-9.591)\end{array}$ & $\begin{array}{c}-0.036 * * * \\
(-4.458)\end{array}$ & $\begin{array}{c}-0.507 * * * \\
(-34.249)\end{array}$ & $\begin{array}{c}-0.543 * * * \\
(-43.831)\end{array}$ \\
\hline $\begin{array}{l}\text { Num. Obs } \\
\text { Adjusted R-squa. }\end{array}$ & $\begin{array}{l}17,613 \\
0.105\end{array}$ & & & & \\
\hline
\end{tabular}

Source: Authors

The results reported in table 3 panel, A and panel B, support our hypothesis (H1) that conservatism is present in a corporate accounting practice in European countries. These results are robust to the use of the two measures of conditional conservatism.

To make the interpretation of results easier, we organize the results in the following summary table 4 .

In short, we find empirical evidence of conservative accounting practice in all the seventeen countries in the sample and in the pool of countries. Such finding is in line with prior studies reporting a conservative accounting practice. Regarding timely gain recognition, the results support this accounting practice using both measures (Basu and Ball and Shivakumar) in ten (Austria, Belgium, Denmark, Finland, France, Germany, Greece, Italy, Sweden, and Switzerland) of the seventeen countries in the sample. This may be interpreted as strong evidence of anticipation in recognition of good news in earnings. In the case of Ireland, none of the measures support timeliness in gain recognition. In the remaining six countries (Czech Republic, Netherlands, Norway, Portugal, Spain, and the UK) one of the two measures is consistent with anticipation of gains in earnings. In short, we also find significant evidence of timeliness in gain recognition in European countries. 
Table 4. Summary of conservative accounting practice in European countries (1998-2018)

\begin{tabular}{lcccc}
\hline & \multicolumn{2}{c}{ Timely Gain Recognition } & \multicolumn{2}{c}{ Conservatism } \\
\cline { 2 - 5 } & Basu & $\begin{array}{c}\text { Ball and } \\
\text { Shivakumar }\end{array}$ & Basu & $\begin{array}{c}\text { Ball and } \\
\text { Shivakumar }\end{array}$ \\
\hline Pool & YES & YES & YES & YES \\
Austria & YES & YES & YES & YES \\
Belgium & YES & YES & YES & YES \\
Czech Rep & YES $(10 \%)$ & NO & YES $(5 \%)$ & YES \\
Denmark & YES & YES & YES & YES \\
Finland & YES & YES & YES & YES \\
France & YES & YES & YES & YES \\
Germany & YES & YES & YES & YES \\
Greece & YES & YES & YES & YES \\
Ireland & NO & NO & YES & YES \\
Italy & YES & YES & YES & YES \\
Netherlands & NO & YES & YES & YES \\
Norway & YES $(10 \%)$ & NO & YES & YES \\
Portugal & NO & YES $(5 \%)$ & YES & YES \\
Spain & NO & YES & YES & YES \\
Sweden & YES & YES & YES & YES \\
Switzerland & YES & YES & YES & YES \\
UK & NO & YES & YES & YES \\
\hline
\end{tabular}

Source: Authors

\section{Comparing accounting conservatism across European countries}

Although the results reported above show that all European countries exhibit a conservative accounting practice, the arguments presented in the development of our hypothesis suggest a less conservative accounting in Anglo-Saxon countries (Ireland and the $\mathrm{UK}$ ) relative to the remaining.

To compare conservatism in Anglo-Saxon countries with the remaining countries in the sample, we estimate modified versions of the regressions of Basu (1997) and Ball and Shivakumar (2005). For that purpose, we include a dummy variable denoted by (Angl) that is set to one for Anglo-Saxon countries and zero otherwise, see table 5. Because of the conservative accounting practice in all countries, we expect the coefficient $\left(\beta_{3}\right)$ to be positive (negative) for Basu (Ball and Shivakumar) regression. In addition, under the assumption of more conservative accounting practice in Continental Europe countries, the coefficient $\left(\beta_{7}\right)$, which captures the incremental sensitivity of the country, is expected to be negative (positive) for the Basu (Ball and Shivakumar) regression. 


\section{Table 5. Comparing accounting conservatism in Anglo-Saxon countries to the remaining}

This table reports the results for a modified version of the Basu (1997) and Ball and Shivakumar (2005) regressions using the sample period from 1998 to 2018. The modified Basu (1997) regression:

$$
\begin{gathered}
\frac{X_{i t}}{P_{i, t-1}}=\beta_{0}+\beta_{1} D_{i t}+\beta_{2} R_{i t}+\beta_{3} D_{i t} * R_{i t}+\beta_{4} A n g l+\beta_{5} A n g l * D_{i t}+\beta_{6} A n g l * R_{i t}+\beta_{7} A n g l \\
* D_{i t} * R_{i t}+e_{i t}
\end{gathered}
$$

Where $\mathrm{X}$ is earnings per share, $\mathrm{P}$ is the stock price, $\mathrm{R}$ is stock return, and $\mathrm{D}$ is a dummy variable that is set to one if the stock return is negative and zero otherwise. The dummy variable "Angl" represents Anglo-Saxon countries.

For the Ball and Shivakumar (2005) regression:

$$
\begin{array}{r}
\Delta N I_{i, t}=\beta_{0}+\beta_{1} D \Delta N I_{i, t-1}+\beta_{2} \Delta N I_{i, t-1}+\beta_{3} D \Delta N I_{i, t-1} * \Delta N I_{i, t-1}+\beta_{4} A n g l+\beta_{5} A n g l \\
* D \Delta N I_{i, t-1}+\beta_{6} \text { Angl } * \Delta N I_{i, t-1}+\beta_{7} A n g l * D \Delta N I_{i, t-1} * \Delta N I_{i, t-1}+\varepsilon_{i, t}
\end{array}
$$

Where $(\Delta N I)$ represents the change in net income scaled by the beginning of year total assets and $(D \Delta N I)$ is a dummy variable that takes the value one when the change in net income in the prior year is negative and zero otherwise. The dummy variable (Angl) represents Anglo-Saxon

\begin{tabular}{|c|c|c|c|c|}
\hline & \multicolumn{2}{|c|}{ Basu Regression } & \multicolumn{2}{|c|}{$\begin{array}{l}\text { Ball and Shivakumar } \\
\text { Regression }\end{array}$} \\
\hline & $\boldsymbol{\beta}_{3}$ & $\beta_{7}$ & $\boldsymbol{\beta}_{3}$ & $\boldsymbol{\beta}_{7}$ \\
\hline Anglo vs. Remaining & $\begin{array}{r}0.156 * * * \\
(40.481)\end{array}$ & $\begin{array}{l}0.091 * * * \\
(12.586)\end{array}$ & $\begin{array}{c}-0.414 * * * \\
(-41.327)\end{array}$ & $\begin{array}{c}-0.098 \\
(-5.512)\end{array}$ \\
\hline Num. Obs & 66,811 & & 62,740 & \\
\hline Adjusted R-squa. & 0.114 & & 0.085 & \\
\hline Nordic vs. Remaining & $\begin{array}{r}0.180 * * * \\
(49.650)\end{array}$ & $\begin{array}{c}0.017 * * \\
(2.137)\end{array}$ & $\begin{array}{r}-0.448 * * * \\
(-49.230)\end{array}$ & $\begin{array}{c}0.023 \\
(1.039)\end{array}$ \\
\hline Num. Obs & 66,811 & & 62,740 & \\
\hline Adjusted R-squa. & 0.111 & & 0.085 & \\
\hline
\end{tabular}
countries. All continuous variables are winsorized at the 1st and 99th percentiles.

Notes: $* * *, * *, *$ indicate significance at the 1 percent, 5 percent, and 10 percent levels, respectively. t-statistics are presented in parentheses.

In the case of Anglo-Saxon countries, the coefficient $\left(\beta_{7}\right)$, which captures the incremental sensitivity of firms in those countries to bad news is positive for the Basu regression. This evidence does not support our second hypothesis (H2) that Continental European countries exhibit a more conservative accounting practice than the AngloSaxon countries. Conversely, the estimations suggest a more conservative accounting practice in Anglo-Saxon countries relative to the remaining countries. In short, the results show evidence of a significant conservative accounting practice for the pool of countries, however, opposite to that expected, the results do not support a more conservative accounting in Continental European countries relative to the Anglo-Saxon countries. A likely explanation is that we must account for the relevance of accounting conservatism to reduce information asymmetries between managers and outside shareholders and that this may be important in the case of countries with developed equity markets, for example the UK. 
We develop additional estimations to compare conservatism between Nordic countries (Denmark, Finland, Netherlands, Norway, and Sweden) and the remaining countries because those countries jointly with Anglo-Saxon countries are included by Gray (1988) among optimistic countries. Estimated coefficients are reported in table 5. While the Basu (1997) regression provides evidence (5\% significance level) of more conservative accounting practice in Nordic countries in the Ball and Shivakumar (2005) regression the coefficient that reflects the incremental sensitivity to bad news is not statistically significant. Therefore, we do not find significant differences between Nordic countries and the remaining countries regarding conservative accounting practice.

\section{Testing the impact of IFRS adoption on conservative accounting practice}

To analyse the impact of IFRS adoption on conservatism, we use an approach that consists in including the dummy variable IFRS that is set to one for firms that follow IFRS and zero otherwise, and the corresponding interaction terms. The coefficient of interest is $\left(\beta_{7}\right)$ that reflects the incremental sensitivity of earnings (income for Ball and Shivakumar) to losses relative to gains after the adoption of IFRS. Table 6 reports the results of estimations.

\section{Table 6. Impact of IFRS adoption on conservatism in European countries}

This table reports the results for a modified version of the Basu (1997) and Ball and Shivakumar (2005) regressions using the sample period from 1998 to 2018. The modified Basu (1997) regression:

$$
\begin{gathered}
\frac{X_{i t}}{P_{i, t-1}}=\beta_{0}+\beta_{1} D_{i t}+\beta_{2} R_{i t}+\beta_{3} D_{i t} * R_{i t}+\beta_{4} I F R S+\beta_{5} I F R S * D_{i t}+\beta_{6} I F R S * R_{i t}+\beta_{7} I F R S \\
* D_{i t} * R_{i t}+e_{i t}
\end{gathered}
$$

Where $\mathrm{X}$ is earnings per share, $\mathrm{P}$ is the stock price, $\mathrm{R}$ is stock return, and $\mathrm{D}$ is a dummy variable that is set to one if the stock return is negative and zero otherwise. The dummy variable "IFRS" represents firms that follow IFRS.

For the Ball and Shivakumar (2005) regression:

$$
\begin{array}{r}
\Delta N I_{i, t}=\beta_{0}+\beta_{1} D \Delta N I_{i, t-1}+\beta_{2} \Delta N I_{i, t-1}+\beta_{3} D \Delta N I_{i, t-1} * \Delta N I_{i, t-1}+\beta_{4} I F R S+\beta_{5} I F R S \\
* D \Delta N I_{i, t-1}+\beta_{6} \text { IFRS } * \Delta N I_{i, t-1}+\beta_{7} I F R S * D \Delta N I_{i, t-1} * \Delta N I_{i, t-1}+\varepsilon_{i, t}
\end{array}
$$

Where $(\Delta N I)$ represents the change in net income scaled by the beginning of year total assets and $(D \Delta N I)$ is a dummy variable that takes the value one when the change in net income in the prior year is negative and zero otherwise.

The dummy variable (IFRS) is set to one for firms that follow IFRS, for most of the firms, after the mandatory adoption of IFRS. All continuous variables are winsorized at the 1st and 99th

\begin{tabular}{|c|c|c|c|c|c|c|}
\hline & \multicolumn{2}{|c|}{ Basu Regression } & & \multicolumn{3}{|c|}{ Ball and Shivakumar Regression } \\
\hline & $\beta_{3}$ & $\boldsymbol{\beta}_{7}$ & $\beta_{3}+\beta_{7}$ & $\boldsymbol{\beta}_{3}$ & $\boldsymbol{\beta}_{7}$ & $\beta_{3}+\beta_{7}$ \\
\hline Pool & $\begin{array}{c}0.204 * * \\
* \\
(38.144)\end{array}$ & $\begin{array}{c}- \\
0.029 * * * \\
(-4.259)\end{array}$ & $\begin{array}{r}0.175 * * * \\
(42.935)\end{array}$ & $\begin{array}{c}-0.543 * * * \\
(-37.842)\end{array}$ & $\begin{array}{c}0.133 * * * \\
(7.555)\end{array}$ & $\begin{array}{c}-0.411 * * * \\
(-40.506)\end{array}$ \\
\hline Num. Obs & 66,811 & & & 62,740 & & \\
\hline Adj. R-squa. & 0.112 & & & 0.086 & & \\
\hline
\end{tabular}
percentiles.

Notes: ***, **, * indicate significance at the 1 percent, 5 percent, and 10 percent levels, respectively. t-statistics are presented in parentheses. 


\begin{tabular}{|c|c|c|c|c|c|c|}
\hline Austria & $\begin{array}{c}0.127 * * \\
* \\
(2.649)\end{array}$ & $\begin{array}{c}-0.085 \\
(-1.598)\end{array}$ & $\begin{array}{l}0.042 * \\
(1.837)\end{array}$ & $\begin{array}{c}-0.718^{* * * *} \\
(-5.505)\end{array}$ & $\begin{array}{c}-0.063 \\
(-0.391)\end{array}$ & $\begin{array}{c}-0.781 * * * \\
(-8.406)\end{array}$ \\
\hline Num. Obs & 935 & & & 886 & & \\
\hline Adj. R-squa. & 0.152 & & & 0.183 & & \\
\hline Belgium & $\begin{array}{c}0.155^{* *} \\
* \\
(5.098)\end{array}$ & $\begin{array}{c}-0.082^{* * *} \\
(-2.162)\end{array}$ & $\begin{array}{c}0.073 * * * \\
(3.317)\end{array}$ & $\begin{array}{c}-0.646^{* * * *} \\
(-6.748)\end{array}$ & $\begin{array}{c}0.457 * * * \\
(3.776)\end{array}$ & $\begin{array}{c}-0.189 * * * \\
(-2.566)\end{array}$ \\
\hline Num. Obs & 1,578 & & & 1,482 & & \\
\hline Adj. R-squa. & 0.139 & & & 0.112 & & \\
\hline Czech Rep & $\begin{array}{r}0.195 * * \\
(2.129)\end{array}$ & $\begin{array}{c}-0.146 \\
(-1.305)\end{array}$ & $\begin{array}{c}0.049 \\
(0.758)\end{array}$ & $\begin{array}{c}-1.320 * * * \\
(-5.626)\end{array}$ & $\begin{array}{c}1.137 * * * \\
(3.917)\end{array}$ & $\begin{array}{c}-0.183 \\
(-1.064)\end{array}$ \\
\hline Num. Obs & 291 & & & 259 & & \\
\hline Adj. R-squa. & 0.065 & & & 0.213 & & \\
\hline Denmark & $\begin{array}{r}0.232 * * * \\
(6.023)\end{array}$ & $\begin{array}{c}-0.062 \\
(-1.358)\end{array}$ & $\begin{array}{c}0.170 * * * \\
(6.825)\end{array}$ & $\begin{array}{c}-0.572 * * * \\
(-6.386)\end{array}$ & $\begin{array}{c}-0.073 \\
(-0.643)\end{array}$ & $\begin{array}{c}-0.645 * * * \\
(-9.284)\end{array}$ \\
\hline Num. Obs & 1,946 & & & 1,839 & & \\
\hline Adj. R-squa. & 0.150 & & & 0.129 & & \\
\hline Finland & $\begin{array}{l}0.110 * * * \\
(4.512)\end{array}$ & $\begin{array}{l}-0.050 * \\
(-1.632)\end{array}$ & $\begin{array}{c}0.060 * * * \\
(3.205)\end{array}$ & $\begin{array}{c}-0.157 \\
(-1.509)\end{array}$ & $\begin{array}{c}-0.126 \\
(-1.019)\end{array}$ & $\begin{array}{c}-0.283 * * * \\
(-4.210)\end{array}$ \\
\hline Num. Obs & 2,046 & & & 1,955 & & \\
\hline Adj. R-squa. & 0.140 & & & 0.068 & & \\
\hline France & $\begin{array}{r}0.158 * * * \\
(13.125\end{array}$ & $\begin{array}{c}-0.062 * * * \\
(-4.143)\end{array}$ & $\begin{array}{c}0.096 * * * \\
(11.058)\end{array}$ & $\begin{array}{c}-0.540 * * * \\
(-15.132)\end{array}$ & $\begin{array}{c}0.166^{* * * *} \\
(3.759)\end{array}$ & $\begin{array}{l}-0.374 * * * \\
(-14.354)\end{array}$ \\
\hline Num. Obs & 10,723 & & & 10,050 & & \\
\hline Adj. R-squa. & 0.109 & & & 0.073 & & \\
\hline Germany & $\begin{array}{r}0.242 * * * \\
(16.750)\end{array}$ & $\begin{array}{c}-0.131 * * * \\
(-7.056)\end{array}$ & $\begin{array}{c}0.111 * * * \\
(9.532)\end{array}$ & $\begin{array}{c}-0.548 * * * \\
(-13.383)\end{array}$ & $\begin{array}{c}0.100 * * \\
(1.983)\end{array}$ & $\begin{array}{c}-0.448 * * * \\
(-15.262)\end{array}$ \\
\hline Num. Obs & 8,289 & & & 7,899 & & \\
\hline Adj. R-squa. & 0.116 & & & 0.095 & & \\
\hline Greece & $\begin{array}{r}0.056 * * * \\
(2.445)\end{array}$ & $\begin{array}{l}0.386 * * * \\
(10.629)\end{array}$ & $\begin{array}{l}0.442 * * * \\
(15.618)\end{array}$ & $\begin{array}{c}-0.078 \\
(-1.163)\end{array}$ & $\begin{array}{c}-0.319 * * * \\
(-3.883)\end{array}$ & $\begin{array}{c}-0.397 * * * \\
(-8.453)\end{array}$ \\
\hline Num. Obs & 4,171 & & & 3,857 & & \\
\hline Adj. R-squa. & 0.141 & & & 0.074 & & \\
\hline Ireland & $\begin{array}{r}0.130^{* *} \\
(1.999)\end{array}$ & $\begin{array}{c}0.054 \\
(0.656)\end{array}$ & $\begin{array}{c}0.184 * * * \\
(3.695)\end{array}$ & $\begin{array}{c}-1.231 * * * \\
(-6.323)\end{array}$ & $\begin{array}{c}0.720 * * * \\
(3.015)\end{array}$ & $\begin{array}{c}-0.511 * * * \\
(-3.699)\end{array}$ \\
\hline Num. Obs & 497 & & & 468 & & \\
\hline Adj. R-squa. & 0.097 & & & 0.148 & & \\
\hline Italy & $\begin{array}{r}0.151 * * * \\
(5.230)\end{array}$ & $\begin{array}{c}-0.092 * * * \\
(-2.753)\end{array}$ & $\begin{array}{c}0.059 * * * \\
(3.430)\end{array}$ & $\begin{array}{c}0.058 \\
(1.050)\end{array}$ & $\begin{array}{c}-0.387 * * * \\
(-5.488)\end{array}$ & $\begin{array}{c}-0.329 * * * \\
(-7.450)\end{array}$ \\
\hline Num. Obs & 3,381 & & & 3,255 & & \\
\hline Adj. R-squa. & 0.077 & & & 0.047 & & \\
\hline Netherlands & $\begin{array}{r}0.270 * * * \\
(10.232)\end{array}$ & $\begin{array}{c}-0.176^{* * * *} \\
(-4.968)\end{array}$ & $\begin{array}{c}0.094 * * * \\
(3.982)\end{array}$ & $\begin{array}{c}-0.645 * * * \\
(-6.970)\end{array}$ & $\begin{array}{c}0.287 * * * \\
(2.499)\end{array}$ & $\begin{array}{c}-0.358 * * * \\
(-5.283)\end{array}$ \\
\hline Num. Obs & 1,800 & & & 1,687 & & \\
\hline Adj. R-squa. & 0.141 & & & 0.120 & & \\
\hline Norway & $\begin{array}{r}0.281 * * * \\
(7.790)\end{array}$ & $\begin{array}{c}-0.038 \\
(-0.845)\end{array}$ & $\begin{array}{c}0.243 * * * \\
(8.931)\end{array}$ & $\begin{array}{c}-0.993 * * * \\
(-12.692)\end{array}$ & $\begin{array}{c}0.731 * * * \\
(7.525)\end{array}$ & $\begin{array}{c}-0.262 * * * \\
(-4.536)\end{array}$ \\
\hline Num. Obs & 2,475 & & & 2,343 & & \\
\hline Adj. R-squa. & 0.132 & & & 0.112 & & \\
\hline Portugal & $\begin{array}{r}0.190 * * \\
(2.140)\end{array}$ & $\begin{array}{c}0.079 \\
(0.755)\end{array}$ & $\begin{array}{c}0.269 * * * \\
(4.782)\end{array}$ & $\begin{array}{c}-0.732 * * * \\
(-4.950)\end{array}$ & $\begin{array}{c}0.462 * * * \\
(2.657)\end{array}$ & $\begin{array}{c}-0.270 * * * \\
(-2.964)\end{array}$ \\
\hline $\begin{array}{l}\text { Num. Obs } \\
\text { Adj. R-squa. }\end{array}$ & $\begin{array}{l}899 \\
0.059\end{array}$ & & & $\begin{array}{l}840 \\
0.103\end{array}$ & & \\
\hline Spain & $\begin{array}{l}0.051 \\
(1.548)\end{array}$ & $\begin{array}{c}0.096 * * \\
(2.362)\end{array}$ & $\begin{array}{c}0.147 * * * * \\
(6.042)\end{array}$ & $\begin{array}{c}-0.610 * * * \\
(-4.459)\end{array}$ & $\begin{array}{c}0.051 \\
(0.338)\end{array}$ & $\begin{array}{c}-0.559 * * * \\
(-8.894)\end{array}$ \\
\hline
\end{tabular}




\begin{tabular}{|c|c|c|c|c|c|c|}
\hline $\begin{array}{l}\text { Num. Obs } \\
\text { Adj. R-squa. }\end{array}$ & $\begin{array}{l}1,818 \\
0.080 \\
\end{array}$ & & & $\begin{array}{l}1,726 \\
0.109 \\
\end{array}$ & & \\
\hline Sweden & $\begin{array}{r}0.307 * * * \\
(14.269)\end{array}$ & $\begin{array}{c}-0.116^{* * * *} \\
(-4.468)\end{array}$ & $\begin{array}{c}0.191 * * * \\
(13.163)\end{array}$ & $\begin{array}{c}-0.526^{* * * *} \\
(-8.485)\end{array}$ & $\begin{array}{c}0.184 * * * \\
(2.542)\end{array}$ & $\begin{array}{c}-0.342 * * * \\
(-9.168)\end{array}$ \\
\hline $\begin{array}{l}\text { Num. Obs } \\
\text { Adj. R-squa. }\end{array}$ & $\begin{array}{l}5,081 \\
0.147\end{array}$ & & & $\begin{array}{l}4,784 \\
0.060\end{array}$ & & \\
\hline Switzerland & $\begin{array}{r}0.145^{* * * *} \\
(8.728)\end{array}$ & $\begin{array}{c}-0.127 * * * \\
(-5.857)\end{array}$ & $\begin{array}{c}0.018 \\
(1.291)\end{array}$ & $\begin{array}{c}-0.493 * * * \\
(-5.075)\end{array}$ & $\begin{array}{c}0.074 \\
(0.624)\end{array}$ & $\begin{array}{c}-0.419 * * * \\
(-6.287)\end{array}$ \\
\hline $\begin{array}{l}\text { Num. Obs } \\
\text { Adj. R-squa. }\end{array}$ & $\begin{array}{l}1,883 \\
0.176\end{array}$ & & & $\begin{array}{l}1,797 \\
0.089\end{array}$ & & \\
\hline UK & $\begin{array}{r}0.250 * * * \\
(22.778)\end{array}$ & $\begin{array}{c}-0.001 \\
(-0.042)\end{array}$ & $\begin{array}{c}0.249 * * * \\
(32.051)\end{array}$ & $\begin{array}{c}-0.643 * * * \\
(-25.463)\end{array}$ & $\begin{array}{c}0.190 * * * \\
(6.104)\end{array}$ & $\begin{array}{l}-0.453 * * * \\
(-25.062)\end{array}$ \\
\hline $\begin{array}{l}\text { Num. Obs } \\
\text { Adj. R-squa. }\end{array}$ & $\begin{array}{l}18,998 \\
0.133\end{array}$ & & & $\begin{array}{l}17,613 \\
0.108\end{array}$ & & \\
\hline
\end{tabular}

Source: Authors

To simplify the analysis, we construct the summary table 7 , where a decrease (increase) in conservatism is considered if there is a significant change identified in either the Basu (1997) model or the Ball and Shivakumar (2005) model.

Table 7. Summary of the impact of IFRS adoption on accounting conservative practice

\begin{tabular}{lccc}
\hline & Before IFRS & After IFRS & Change with IFRS \\
\hline Pool & Conservative & Conservative & Decrease \\
Austria & Conservative & Conservative & Decrease (Basu) \\
Belgium & Conservative & Conservative & Decrease \\
Czech Rep & Conservative & No significant & Decrease \\
Finland & Conservative (Basu) & Conservative & Decrease (Basu) \\
France & Conservative & Conservative & Decrease \\
Germany & Conservative & Conservative & Decrease \\
Ireland & Conservative & Conservative & Decrease \\
Netherlands & Conservative & Conservative & (Ball\&Shiv) \\
Norway & Conservative & Conservative & Decrease \\
Portugal & Conservative & Conservative & (Ball\&Shiv) \\
Sweden & Conservative & Conservative & Decrease \\
Switzerland & Conservative & Conservative & Decrease \\
UK & (Ball\&Shiv) & Decrease (Basu) \\
\hline Greece & Conservative & Conservative & Decrease \\
Spain & Conservative (Basu) & Conservative & (Ball\&Shiv) \\
Denmark & Conservative & Increase \\
Italy & Conservative & Increase (Basu) \\
\hline Cource: $A$ Shiv) & Conservative & No significant \\
\hline & Conservative (Basu) & Conservative & No conclusive \\
\hline
\end{tabular}

Source: Authors 
The most relevant finding is the conservative accounting practice in the pool of countries and in all individual European countries before and after the adoption of IFRS, except in the case of the Czech Republic after the adoption using either of the two models. Another significant result suggests a decrease in the level of conservatism after the adoption of IFRS in the pool and in all the countries, except for Greece, Spain, Denmark, and Italy. This result represents strong empirical evidence on the decrease of conservatism after the adoption and supports our third hypothesis (H3).

Now we focus on some details present in the results. In the case of Greece and Spain, we find evidence of an increase in the level of conservatism. In the case of Italy, there is a decrease in conservatism by the Basu (1997) model and an increase the usage of the Ball and Shivakumar (2005) model. In the case of Denmark, the change in the level of conservatism is not statistically significant. Another case we must emphasise is the evidence relative to the UK because of the large number of observations and also because of the similarities between accounting standards before and after the IFRS adoption. Taking into account the similarities in accounting standards, we would expect a small change in the level of conservatism. In fact, such change (decrease) is only significant using the Ball and Shivakumar (2005) measure but is not statistically significant using the Basu (1997) measure.

\section{Testing the impact of economic conditions on conservative accounting practice}

To analyse the impact of economic conditions on conservatism, we use an approach that consists in including a dummy variable that captures economic conditions. This dummy variable denoted in the equation by (Econ) alternates between representing the pre and crisis period, is set to one for the period of four years from 2005 to 2008 and representing the post-crisis period, is set to one for the period from 2009 to 2012. The coefficient of interest is $\left(\beta_{7}\right)$ that reflects the incremental sensitivity of earnings (income for Ball and Shivakumar) to losses relative to gains given the change in economic conditions. Table 8 reports the results of the estimations.

\section{Table 8. Impact of economic conditions on conservatism in European countries}

This table reports the results for a modified version of the Basu (1997) and Ball and Shivakumar (2005) regressions using the sample period from 1998 to 2018. The modified Basu (1997) regression:

$$
\begin{gathered}
\frac{X_{i t}}{P_{i, t-1}}=\beta_{0}+\beta_{1} D_{i t}+\beta_{2} R_{i t}+\beta_{3} D_{i t} * R_{i t}+\beta_{4} E \operatorname{con}+\beta_{5} E \operatorname{con} * D_{i t}+\beta_{6} E \operatorname{con} * R_{i t}+\beta_{7} E c o n \\
* D_{i t} * R_{i t}+e_{i t}
\end{gathered}
$$

Where $\mathrm{X}$ is earnings per share, $\mathrm{P}$ is the stock price, $\mathrm{R}$ is stock return, and $\mathrm{D}$ is a dummy variable that is set to one if the stock return is negative and zero otherwise. The dummy variable (Econ) alternates between representing the pre and crisis period and the post-crisis period.

For the Ball and Shivakumar (2005) regression:

$$
\begin{aligned}
& \Delta N I_{i, t}=\beta_{0}+\beta_{1} D \Delta N I_{i, t-1}+\beta_{2} \Delta N I_{i, t-1}+\beta_{3} D \Delta N I_{i, t-1} * \Delta N I_{i, t-1}+\beta_{4} E \operatorname{con}+\beta_{5} E \operatorname{con} \\
& * D \Delta N I_{i, t-1}+\beta_{6} E \operatorname{con} * \Delta N I_{i, t-1}+\beta_{7} E \operatorname{con} * D \Delta N I_{i, t-1} * \Delta N I_{i, t-1}+\varepsilon_{i, t}
\end{aligned}
$$

Where $(\Delta N I)$ represents the change in net income scaled by the beginning of year total assets and $(D \Delta N I)$ is a dummy variable that takes the value one when the change in net income in the prior year is negative and zero otherwise. The dummy variable (Econ) alternates between representing 
the pre and crisis period and the post-crisis period. All continuous variables are winsorized at the 1st and 99th percentiles.

Notes: ***, **, * indicate significance at the 1 percent, 5 percent, and 10 percent levels, respectively. t-statistics are presented in parentheses.

\begin{tabular}{|c|c|c|c|c|c|c|}
\hline \multirow[b]{3}{*}{$\begin{array}{c}\text { Pre } \\
\text { Crisis }\end{array}$} & \multicolumn{2}{|c|}{ Basu Regression } & \multicolumn{4}{|c|}{ Ball and Shivakumar Regression } \\
\hline & $\beta_{3}$ & $\beta_{7}$ & $\boldsymbol{\beta}_{3}+\boldsymbol{\beta}_{7}$ & $\beta_{3}$ & $\boldsymbol{\beta}_{7}$ & $\boldsymbol{\beta}_{3}+\boldsymbol{\beta}_{7}$ \\
\hline & $\begin{array}{l}0^{0.238^{*}} \\
* * \\
\quad(62.241 \\
\end{array}$ & $\begin{array}{l}- \\
0.156 * * * \\
(-20.854)\end{array}$ & $\begin{array}{l}0.082 * * * \\
(12.864)\end{array}$ & $\begin{array}{c}- \\
0.479 * * * \\
(-51.940)\end{array}$ & $\begin{array}{c}0.180 * * * \\
(8.703)\end{array}$ & $\begin{array}{c}-0.299 * * * \\
(-16.172)\end{array}$ \\
\hline Num. Obs & 66,811 & & & 62,740 & & \\
\hline Adj. R-squa. & 0.123 & & & 0.089 & & \\
\hline Post & $\begin{array}{c}0.171 * \\
* * \\
(48.184 \\
)\end{array}$ & $\begin{array}{c}0.089 * * * \\
(10.059)\end{array}$ & $\begin{array}{c}0.260 * * * \\
(32.208)\end{array}$ & $\begin{array}{c}- \\
0.422 * * * \\
(-44.308)\end{array}$ & $\begin{array}{c}-0.110 * * * \\
(-5.812)\end{array}$ & $\begin{array}{c}-0.532 * * * \\
(-32.527)\end{array}$ \\
\hline Num. Obs & 66,811 & & & 62,740 & & \\
\hline Adj. R-squa. & 0.111 & & & 0.088 & & \\
\hline
\end{tabular}

Source: Authors

The coefficient of interest to analyse the change in conservatism in the (Crisis) period is $\left(\beta_{7}\right)$ that is negative and significant (positive and significant) in the Basu (Ball and Shivakumar) model. These results suggest that during crisis accounting conservatism decreases, and this may reflect actions developed by management to avoid reporting negative news to outside stakeholders. In addition, the coefficient to analyse the change in conservatism in the (Post) period is $\left(\beta_{7}\right)$ that is positive and significant (negative and significant) in the Basu (Ball and Shivakumar) model. These results support an increase in conservatism in the post-crisis period consistent with the arguments that conservatism is an efficient contracting and governance mechanism that may help firms to recover from a crisis. Therefore, the results support our two hypotheses regarding the effect of economic conditions: hypothesis (H4.a: the level of conservative accounting practice is lower in the pre and crisis period during the 2007/08 financial crisis) and hypothesis (H4.b the level of conservative accounting practice is higher in the period post the 2007/08 financial crisis).

Testing the impact of the intensity of the economic downturn on conservative accounting practice

As a robustness test and to deepen the analysis of the impact of more severe negative economic conditions on conservatism, we include a new dummy variable, denoted by (Distr) that identifies firms in countries that are usually considered as having been more severely affected by the financial crisis: Greece, Ireland, Portugal, and Spain. 
Table 9. Impact of the intensity of the economic downturn on conservatism in European countries

This table reports the results for a modified version of the Basu (1997) regression using the sample period from 1998 to 2018. The modified Basu (1997) regression:

$$
\begin{aligned}
\frac{X_{i t}}{P_{i, t-1}}=\beta_{0}+\beta_{1} D_{i t} & +\beta_{2} R_{i t}+\beta_{3} D_{i t} * R_{i t}+\beta_{4} E \operatorname{con}+\beta_{5} E \operatorname{con} * D_{i t}+\beta_{6} E \operatorname{con} * R_{i t}+\beta_{7} E \operatorname{con} \\
& * D_{i t} * R_{i t}+\beta_{8} \text { Distr }+\beta_{9} \text { Distr } * D_{i t}+\beta_{10} \text { Distr } * R_{i t}+\beta_{11} \text { Distr } * D_{i t} \\
& * R_{i t}+\beta_{12} \text { Distr } * \text { Econ }+\beta_{13} \text { Distr } * \text { Econ } * D_{i t}+\beta_{14} \text { Distr } * \text { Econ } * R_{i t} \\
& +\beta_{15} \text { Distr } * \text { Econ } * D_{i t} * R_{i t}+e_{i t}
\end{aligned}
$$

Where $\mathrm{X}$ is earnings per share, $\mathrm{P}$ is the stock price, $\mathrm{R}$ is stock return, and $\mathrm{D}$ is a dummy variable that is set to one if the stock return is negative and zero otherwise. The dummy variable "Econ" alternates between representing the pre and crisis period and the post-crisis period. The dummy variable "Distr" takes the value 1 for firms in Greece, Ireland, Portugal, and Spain. All continuous variables are winsorized at the 1st and 99th percentiles.

Notes: $* * *, * *, *$ indicate significance at the 1 percent, 5 percent, and 10 percent levels, respectively. t-statistics are presented in parentheses.

\begin{tabular}{lccccc}
\hline & \multicolumn{5}{c}{ Basu Regression } \\
\cline { 2 - 6 } Pre & $\boldsymbol{\beta}_{\mathbf{3}}$ & $\boldsymbol{\beta}_{\mathbf{7}}$ & $\boldsymbol{\beta}_{\mathbf{3}}+\boldsymbol{\beta}_{\mathbf{7}}$ & $\boldsymbol{\beta}_{\mathbf{1 5}}$ & $\boldsymbol{\beta}_{\mathbf{3}}+\boldsymbol{\beta}_{\mathbf{7}}+\boldsymbol{\beta}_{\mathbf{1 5}}$ \\
\cline { 2 - 6 } Crisis & $0.236^{*}$ & - & & & \\
& $* *$ & $0.151^{* * *}$ & $0.085^{* * *}$ & -0.041 & 0.044 \\
Num. Obs & $(60.760$ & $(-20.069)$ & $(13.149)$ & $(-1.170)$ & $(1.253)$ \\
Adj. R-squa. & 06,811 & & & & \\
\hline Post & 0.125 & & & & \\
\multicolumn{7}{c}{} & $0.173^{*}$ & & & & \\
& $(4 *$ & $0.066^{* * *}$ & $0.239^{* * *}$ & $0.304^{* * *}$ & $0.543^{* * *}$ \\
Num. Obs & 66,811 & $(7.427)$ & $(29.522)$ & $(7.362)$ & $(13.408)$ \\
Adj. R-squa. & 0.115 & & & & \\
\hline
\end{tabular}

Source: Authors

We analyse the change in conservatism in those countries relative to the remaining countries, both in the pre and crisis period and in the post-crisis period; thus we also include the dummy (Econ) that alternates between representing the pre and crisis period and the post-crisis period. Given that we are mainly concerned with the interpretation by outside stakeholders of conservative reporting, we estimate a modified Basu model that uses a market measure as a proxy for bad or good news whose estimation is reported in table 9.

The coefficients of interest to analyse the change in conservatism in the pre and crisis period are $\left(\beta_{7}\right)$ and $\left(\beta_{15}\right)$. The coefficient $\left(\beta_{7}\right)$ is negative and significant, suggesting a decrease in conservatism in that period. However, as reflected by the sum $\left(\beta_{3}+\beta_{7}\right)$, conservatism is still present in that period. In the case of firms in distressed countries, the coefficient that measures the difference in sensitivity is $\left(\beta_{15}\right)$ that is not statistically significant. In addition, the sum $\left(\beta_{3}+\beta_{7}+\beta_{15}\right)$ does not support a conservative accounting for firms in distressed countries in the pre and crisis period. In the case of the post-crisis period, we find significant differences relative to the pre and crisis period. Firstly, there is a significant increase in conservatism relative to the whole sample period $\left(\beta_{7}=0.066 * * *\right)$. Regarding firms in distressed countries, the impact is 
even stronger. The difference in conservatism between distressed countries and the remaining is given by $\left(\beta_{15}=0.304 * * *\right)$ and the coefficient that measures conservatism in those firms in the post-crisis period is $\left(\beta_{3}+\beta_{7}+\beta_{15}=0.543 * * *\right)$ which compares to $\left.\beta_{3}+\beta_{7}=0.239 * * *\right)$ for firms in the remaining countries in the same period. The estimations support our hypothesis $\mathrm{H} 5$ that the impact of the financial crisis on conservatism is stronger for the group of distressed countries. These results are in line with the arguments that conservatism can be seen as an important contracting and governance mechanism that helps firms to recover in situations of economic stress. In addition, these results suggest that IFRS provide enough flexibility that allows management to adjust financial reporting in response to changes in economic conditions.

\section{Conclusions}

We find empirical evidence that conditional accounting conservatism is present in financial reporting practices for listed firms in seventeen European countries. Therefore, our results seem to be in line with the positive accounting theory when suggesting that conservatism is an efficient contracting and governance mechanism.

Another important finding refers to differences in conservatism across European countries. Opposite to the arguments developed in some of the prior studies suggesting a more conservative accounting practice in Continental Europe countries than in AngloSaxon countries, our results show that Anglo-Saxon countries have a more conservative accounting practice than Continental European Countries. Specifically, the results seem not to support the arguments based on the main financing system and conservative culture, pointing to a demand for more conservative accounting in Continental Europe countries. However, the results are in line with the argument that in common-law countries information asymmetries between managers and diverse groups of external shareholders are resolved by accounting information; thus timeliness is a fundamental attribute of earnings, mainly due to timely loss recognition. In the case of Nordic countries, the evidence is not statistically significant.

Regarding the impact of IFRS adoption on conservatism, our findings are consistent with conservative accounting practices before and after this adoption. In addition, the results suggest a decrease in the level of conservatism after the adoption for a large majority of countries. By contrast, we find that in Greece and Spain, the level of conservatism increases after IFRS adoption. In the case of the UK, only one of the measures of conservatism supports such a decrease, consistent with arguments based on similarities between accounting standards before and after IFRS adoption.

Given the potential mixed effects of IFRS adoption and major changes in economic conditions, we also analyse the impact of the 2007/08 financial crisis on accounting practice. We find significant evidence of changes in accounting conservatism in the period from 2005 to 2008 and in the period from 2009 and 2012, relative to the whole sample period. In the pre and crisis period conservatism decreases, suggesting that managers tend to alter accounting numbers to avoid reporting bad news to stakeholders. In the post-crisis period, the level of accounting conservatism increases, consistent with managers using conservatism to help recover their firms because they are aware that 
stakeholders view accounting conservatism as an efficient contracting and governance mechanism to monitor managers' actions.

Therefore, the flexibility underlying IFRS allows adjusting the level of accounting conservatism to the economic conditions.

The opposite signs of the changes in the level of conservatism in the periods (pre and crisis, post-crisis) may explain global changes after IFRS adoption that depend on the intensity of the crisis. In line with this argument, we find that in the cases of Spain and Greece, conservatism increases after IFRS adoption. Thus, we run some tests about the differential impact of the financial crisis in the two periods defined above for the group of countries that are considered to have been more affected by the crisis: Greece, Ireland, Portugal, and Spain. In the pre and crisis period, we find no evidence of conservative accounting in those countries but, in the post-crisis period, we find a level of conservatism that is significantly higher than for the remaining countries, in line with the arguments that conservatism can be seen as an important contracting and governance mechanism that helps firms to recover in situations of economic stress.

Acknowledgements: The authors would like to thank all organisers, referees, and discussant of the 17th International Conference on Finance and Banking, in particular Daniel Stavárek. We also would like to acknowledge the Reviewers of Review of Economic Perspectives for their careful reading of this paper and helpful suggestions.

Disclosure statement: No potential conflict of interest was reported by the authors.

\section{References}

ALI, A., HWANG, L. (2000). Country-specific factors related to financial reporting and the value relevance of accounting data. Journal of Accounting Research, 38(1): 1-22. DOI: $10.2307 / 2672920$

ANDRE, P., FILIP, A. and PAUGAM, L. (2015). The effect of mandatory IFRS adoption on conditional conservatism in Europe. Journal of Business Finance \& Accounting, 42(3) \& (4): 482-514. DOI: 10.1111/jbfa.12105

AUGUSTA, C., (2018). Does accounting conservatism make good news forecasts more credible and bad news forecasts less alarming? Journal of Accounting, Auditing \& Finance, July: 1-37. DOI: 10.1177/0148558X18780550

BALAKRISHNAN, K., WATTS, R. and ZUO, L., (2016). The effect of accounting conservatism on corporate investment during the global financial crisis. Journal of Business Finance \& Accounting, 43(5)\& (6): 513-542. DOI: 10.1111/jbfa.12206

BALL, R., KOTHARI, S. and ROBIN, A., (2000). The effect of international institutional factors on properties of accounting earnings. Journal of Accounting and Economics, 29: 1-51. DOI: 10.1016/S0165-4101(00)00012-4

BALL, R., ROBIN, A. and WU, J., (2003). Incentives versus standards: properties of accounting income in four East Asian countries. Journal of Accounting and Economics, 36: 235-270. DOI: 10.1016/j.jacceco.2003.10.003 
BALL, R., SHIVAKUMAR, L., (2005). Earnings quality in UK private firms: comparative loss recognition timeliness. Journal of Accounting and Economics, 39: 83128. DOI: 10.1016/j.jacceco.2004.04.001

BALL, R., (2006). International Financial Reporting Standards (IFRS): pros and cons for investors. Accounting and Business Research, 36(sup1): 5-27. DOI: 10.1080/00014788.2006.9730040

BALL, R., ROBIN, A. and SADKA, G., (2008). Is financial reporting shaped by equity markets or by debt markets? An international study of timeliness and conservatism. Review of Accounting Studies, 13: 168-205. DOI: 10.1007/s11142-007-9064-X

BALTAGI, B., (2005). Econometric Analysis of Panel Data, 3rd ed., John Wiley \& Sons, Ltd., England.

BARKER, R., MCGEACHIN, A., (2015). An analysis of concepts and evidence on the question of whether IFRS should be conservative. Journal of Accounting Business and Business Studies, 51: 169-207. DOI: 10.1111/abac.12049

BARTH, M., LANDSMAN, W. and LANG, M., (2008). International Accounting Standards and accounting quality. Journal of Accounting Research, 46(3): 467-498. DOI: 10.1111/j.1475-679X.2008.00287.x

BASU, S., (1997). The conservatism principle and the asymmetric timeliness of earnings. Journal of Accounting and Economics, 24: 3-37. DOI: 10.1016/S01654101(97)00014-1

BORKER, D., (2013). Is there a favorable cultural profile for IFRS?: an examination and extension of gray's accounting value hypotheses. International Business \& Economics Research Journal, 12(2): 167-177. DOI: 10.19030/iber.v12i2.7629

CHOI, F., MEEK, G., (2011), International Accounting, Pearson Prentice Hall, 7th ed., US.

FEARNLEY, N., GRAY, S., (2015). National institutional factors and IFRS implementation in Europe: the case of investment property companies. International Journal of Accounting and Information Management, 23(3): 271-288. DOI: 10.1108/IJAIM-05-2014-0038

FRANCIS, B., HASAN, I. and WU, Q., (2013). The benefits of conservative accounting to shareholders: evidence from the financial crisis. The Accounting Review, 27(2): 319346. DOI: $10.2308 /$ acch-50431

GRAY, S., (1988). Towards a theory of cultural influence on the development of accounting systems internationally. Journal of Accounting Finance and Business Studies, 24: 1-15. DOI: 10.1111/j.1467-62811988.tb00200.x

GUENTHER, D., YOUNG, D., (2000). The association between financial accounting measures and real economic activity: a multinational study. Journal of Accounting and Economics, 29: 53-72. DOI: 10.1016/S0165-4101(00)00013-6 
GUNN, J., KHURANA, I. and STEIN, S., (2018). Determinants and consequences of timely asset impairments during the financial crisis. Journal of Business Finance \& Accounting, 45(1) \& (2): 3-39. DOI: 10.1111/jbfa.12287

JENKINS, D., KANE, G. and VELURY, U., (2009). Earnings conservatism and value relevance across the business cycle. Journal of Business Finance \& Accounting, 36(9) \& (10): 1041-1058. DOI: 10.1111/j.1468-5957.2009.02164.x

KOTHARI, S., LESTER, R., (2012). The Role of Accounting in the Financial Crisis: Lessons for the Future. Accounting Horizons, 26(2): 335-351. DOI: 10.2308/acch50134

KVAAL, E., NOBES, C., (2010). International differences in IFRS policy choice: a research note. Accounting and Business Research, 40(2): 173-187. DOI: 10.1080/00014788.2010.9663390

LAFOND, R., ROYCHOWDHURY, S., (2008). Managerial ownership and accounting conservatism. Journal of Accounting Research, 46(1): 101-135. DOI: 10.1111/j.1475679X.2008.00268.X

LAFOND, R., WATTS, R., (2008). The information role of conservatism. The Accounting Review, 83(2): 447-478. DOI: 10.2308/accr.2008.83.2.447

LARA, J., OSMA, B. and PENALVA, F., (2014). Information consequences of accounting conservatism. European Accounting Review, 23(2): 173-198. DOI: 10.1080/09638180.2014.882263

MORA, A., WALKER, M., (2015). The implications of research on accounting conservatism for accounting standard setting. Accounting and Business Research, 45(5): 620-650. DOI: 10.1080/00014788.2015.1048770

MYERS, S., MAJLUF, N., (1984). Corporate financing and investment decisions when firms have information that investors do not have. Journal of Financial Economics, 13(2): 187-221. DOI: 10.1016/0304-405X(84)90023-0

NIKOLAEV, V., (2010). Debt covenants and accounting conservatism. Journal of Accounting Research, 48(1): 137-176. DOI: 10.1111/j.1475-679X.2009.00359.x

NOBES, C., (1998). Towards a general model of the reasons for international differences in financial reporting. Abacus, 34(2): 162-187. DOI: 10.1111/14676281.00028

NOBES, C., (2006). The survival of international differences under IFRS: towards a research agenda. Accounting and Business Research, 36: 233-245. DOI: 10.1080/00014788.2006.9730023

NOBES, C., (2008). Accounting classification in the IFRS era. Australian Accounting Review, 18(3): 191-98. DOI: 10.1111/j.1835-2561.2008.0024.x

NOBES, C., (2011). IFRS practices and the persistence of accounting system classification. ABACUS, 47(3): 267-283. DOI: 10.1111/j.1467-6281.2011.00341.x 
OTHMAN, H., KOSSENTINI, A., (2015). IFRS adoption strategies and theories of economic development. Journal of Accounting in Emerging Economies, 5(1): 70-121. DOI: 10.1108/JAEE-02-2012-0006

RUCH, G., TAYLOR, G., (2015). Accounting conservatism: a review of the literature. Journal of Accounting Literature, 34: 17-38. DOI: 10.1016/j.acclit.2015.02.001

SODAN, S., BARAC, Z. and VUKO, T., (2013). Lessons from financial crisis: has accounting in Central and Eastern Europe countries become more conservative? Economic Research - Special issue: 399-414. DOI: 10.1080/1331677X.2013.11517659

TROMBETTA, M., IMPERATORE, C., (2014). The dynamic of financial crises and its non-monotonic effects on earnings quality. Journal of Account. Public Policy, 33: 205232. DOI: 10.1016/j.jaccpubpol.2014.02.002

VERNEY, S., (2009). Flaky fringe? Southern Europe facing the financial crisis. South European Society and Politics, 14(1): 1-6. DOI: 10.1080/13608740902995794

VICHITSARAWONG, T., ENG, L. and MEEK, G., (2010). The impact of the Asian financial crisis on conservatism and timeliness of earnings: evidence from Hong Kong, Malaysia, Singapore, and Thailand. Journal of International Financial Management \& Accounting, 21: 32-61. DOI: 10.1111/j.1467-646X.2009.01035.x

WATTS, R. L., (2003). Conservatism in accounting - Part I: explanations and implications. Accounting Horizons, 17: 207-221. DOI: 10.2308/acch.2003.17.3.207

WHALEN, C., (2008). The subprime crisis - cause, effect and consequences. Working paper of the Networks Financial Institute at Indiana State University: 1-17.

ZHANG, J., (2008). The contracting benefits of accounting conservatism to lenders and borrowers. Journal of Accounting and Economics, 45: 27-54. DOI: 10.1016/j.jacceco.2007.06.002

ZEGHAL, D., LAHMAR Z., (2018). The effect of culture on accounting conservatism during adoption of IFRS in the EU. International Journal of Accounting \& Information Management, 26(2): 311-330. DOI: 10.1108/IJAIM-08-2016-0077 